RECEIVED

FEB 141996

OSTI

Contamination Source Review for Building E3236, Edgewood Area, Aberdeen Proving Ground, Maryland

Energy Systems Division

Argonne National Laboratory

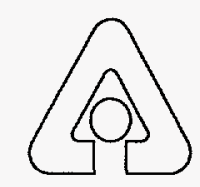

Operated by The University of Chicago,

under Contract W-31-109-Eng-38, for the

United States Department of Energy 


\section{Argonne National Laboratory}

Argonne National Laboratory, with facilities in the states of Illinois and Idaho, is owned by the United States Government, and operated by the University

of Chicago under the provisions of a contract with the Department of Energy.

This technical memo is a product of Argonne's Energy Systems (ES) Division. For information on the division's scientific and engineering activities, contact:

Director, Energy Systems Division

Argonne National Laboratory

Argonne, Illinois 60439-4815

Telephone (708) 252-3724

Presented in this technical memo are preliminary results of ongoing work or work that is more limited in scope and depth than that described in formal reports issued by the ES Division.

Publishing support services were provided by Argonne's Information and Publishing Division (for more information, see IPD's home page: http://www.ipd.anl.gov/).

\section{Disclaimer}

This report was prepared as an account of work sponsored by an agency of the United States Government. Neither the United States Government nor any agency thereof, nor any of their employees, makes any warranty, express or implied, or assumes any legal liability or responsibility for the accuracy, completeness, or usefulness of any information, apparatus, product, or process disclosed, or represents that its use would not infringe privately owned rights. Reference herein to any specific commercial product, process, or service by trade name, trademark, manufacturer, or otherwise, does not necessarily constitute or imply its endorsement, recommendation, or favoring by the United States Government or any agency thereof. The views and opinions of authors expressed herein do not necessarily state or reflect those of the United States Government or any agency thereof.

Available to $D O E$ and $D O E$ contractors from the Office of Scientific and Technical Information, P.O. Box 62, Oak Ridge, TN 37831; prices available from (423) 576-8401.

Available to the public from the National Technical Information Service, U.S. Department of Commerce, 5285 Port Royal Road, Springfield, VA 22161. 


\section{DISCLAIMIER}

Portions of this document may be illegible in electronic image products. Images are produced from the best available original document. 


\section{Contamination Source Review for Building E3236, Edgewood Area, Aberdeen Proving Ground, Maryland}

S.D. Zellmer, M.P. Smits, A.K. Draugelis, M.A. Glennon, J. Rueda, and R.E. Zimmerman

Center for Environmental Restoration Systems, Energy Systems Division,

Argonne National Laboratory, 9700 South Cass Avenue, Argonne, Illinois 60439

Published as

Contamination Source Review

Edgewood Area, Aberdeen Proving

Ground, Maryland -

Building E3236

Work sponsored by United States Department of Defense, United States Army, Aberdeen Proving Ground, Maryland 
बत्

This report is printed on recycled paper. 


\section{Contents}

Summary

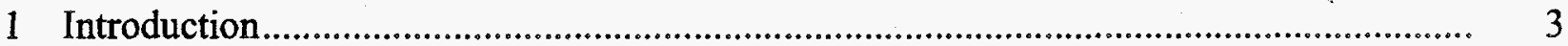

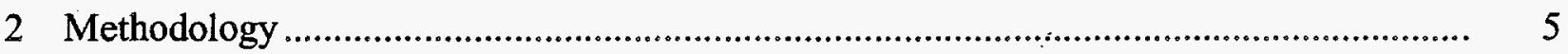

3 Historical Record Search ............................................................................................. 6

4 Building Description.................................................................................................... 8

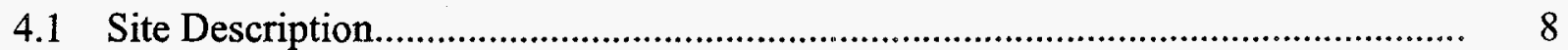

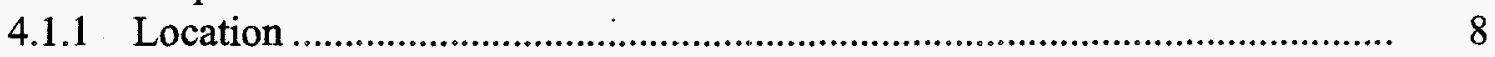

4.1.2 Proximity to Other Buildings....................................................................... 8

4.1.3 Building Structure .................................................................................. 8

4.1.4 Exterior Dimensions ….......................................................................

4.1.5 Topography ......................................................................................... 13

4.1.6 Vegetation in the Immediate Vicinity ........................................................... 13

4.1.7 External Aboveground Structures or Equipment ........................................... 13

4.1.8 Connections with Adjacent Buildings....................................................... 13

4.1.9 Underground Structures ..................................................................... 13

4.1.10 Surface Drainage System ................................................................... 14

4.1.11 Utility Access Points............................................................................. 14

4.1.12 Exterior Piping ................................................................................ 14

4.1.13 Nearby Roads and Sidewalks.............................................................. 14

4.2 North Exterior Elevation............................................................................... 14

4.2.1 Dimensions..................................................................................... 14

4.2.2 Construction Materials....................................................................... 15

4.2.3 Doors and Windows......................................................................... 15

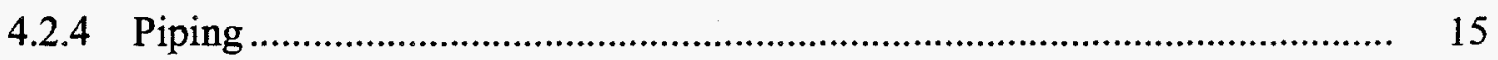

4.2.5 Utility Connections ......................................................................... 15

4.2.6 External Equipment or Structures.......................................................... 15

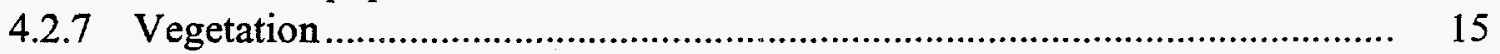

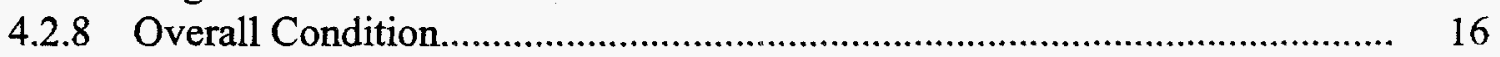

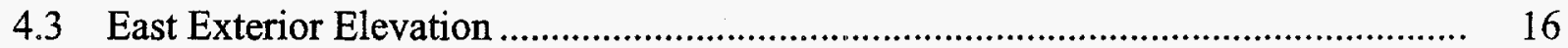

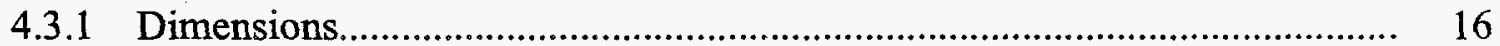

4.3.2 Construction Materials...................................................................... 16

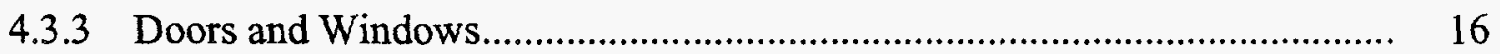

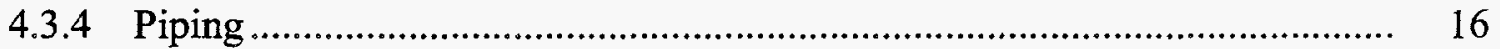

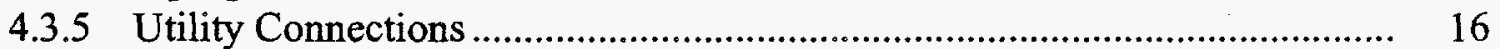

4.3.6 External Equipment or Structures......................................................... 17

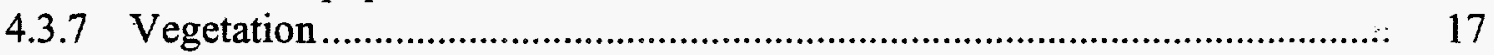

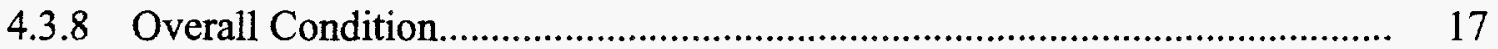




\section{Contents (Cont.)}

4.4 South Exterior Elevation...................................................................................... 17

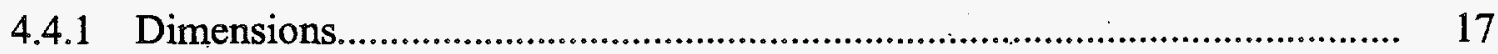

4.4.2 Construction Materials ............................................................................ 17

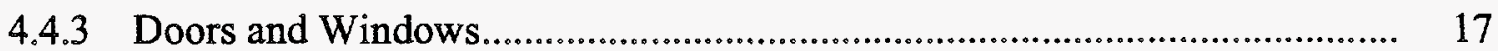

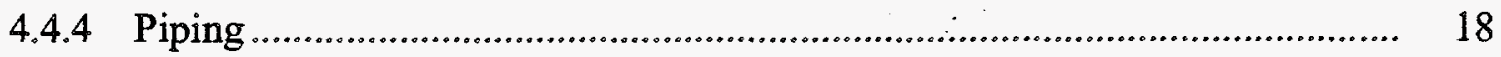

4.4.5 Utility Connections ................................................................................. 18

4.4.6 External Equipment or Structures................................................................ 18

4.4.7 Vegetation........................................................................................... 18

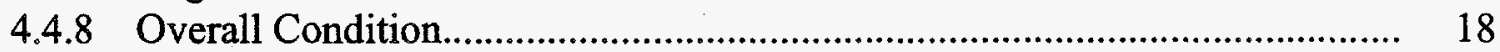

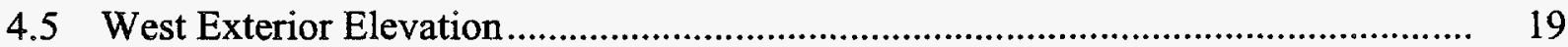

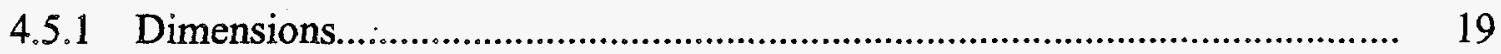

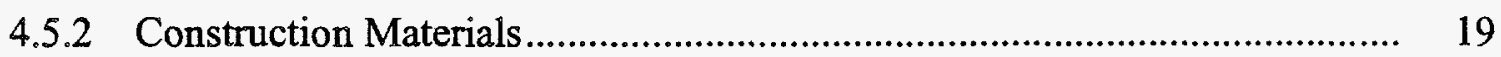

4.5.3 Doors and Windows.............................................................................. 19

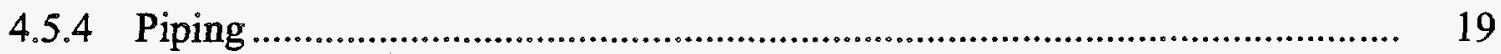

4.5.5 Utility Connections .......................................................................................... 19

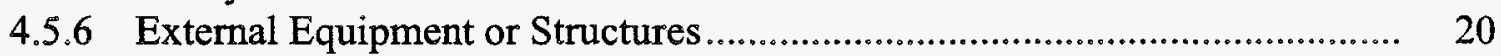

4.5.7 Vegetation ............................................................................................. 20

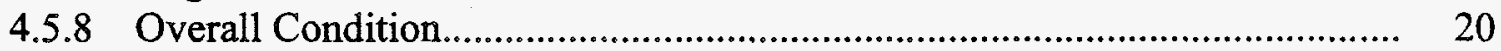

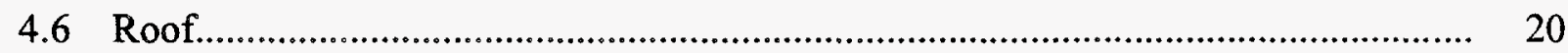

4.6.1 Type and Dimensions............................................................................. 20

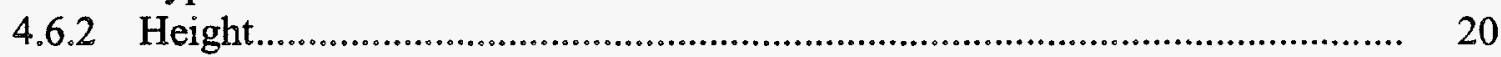

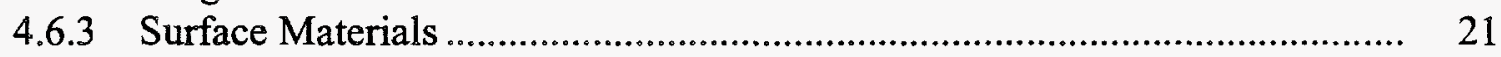

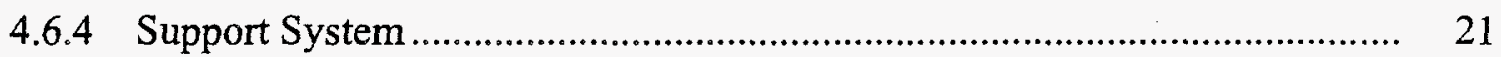

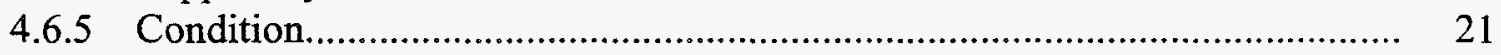

4.6.6 Equipment Located on Roof .................................................................. 21

4.6.7 Chimneys, Roof Vents, or Vent Stacks..................................................... 21

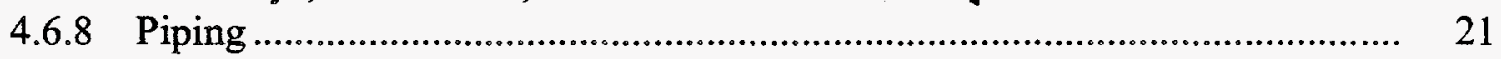

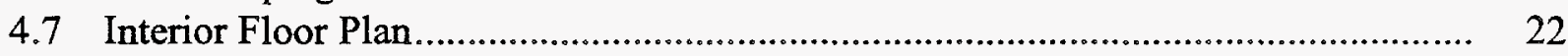

4.7.1 Room Numbers and Dimensions ............................................................. 22

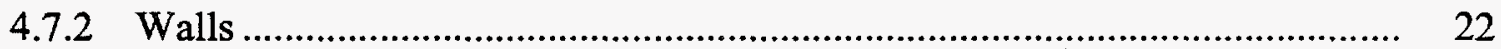

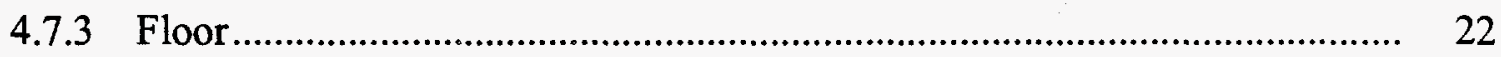

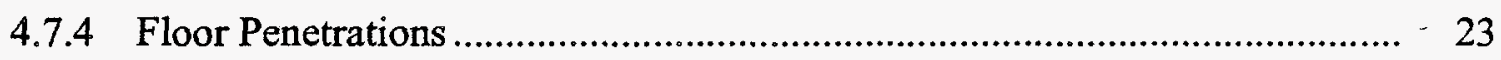

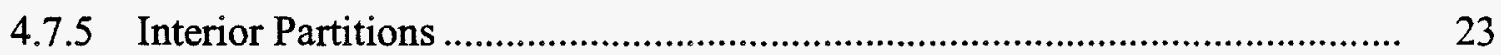

4.7.6 Equipment or Supplies........................................................................... 23

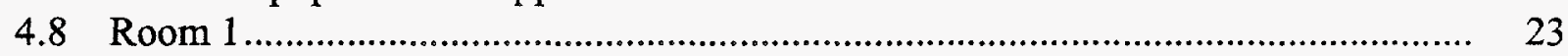

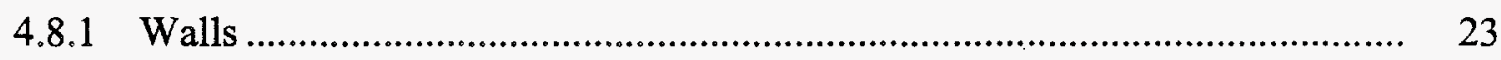

4.8.2 Finish Materials...................................................................................... 23

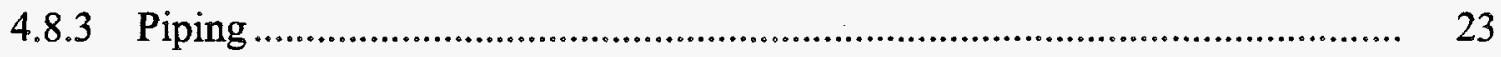

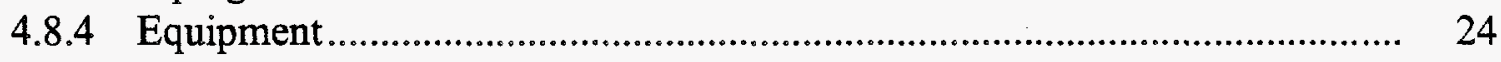

4.8.5 Doors and Windows................................................................................ 24

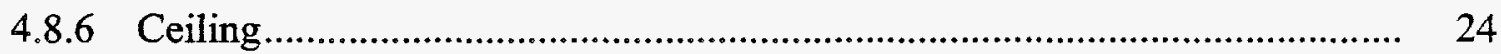

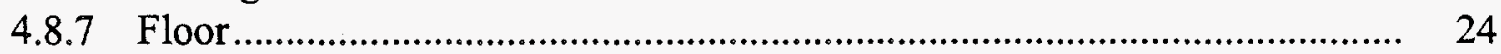




\section{Contents}

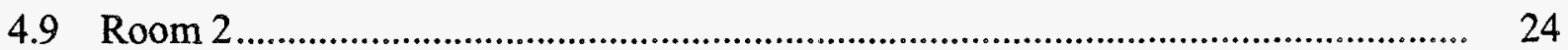

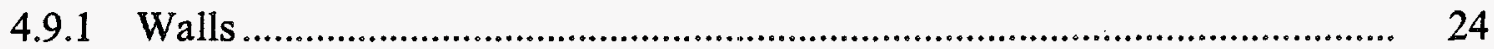

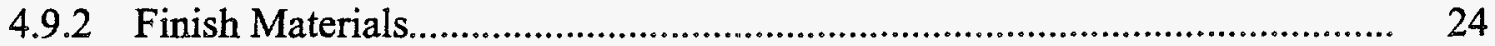

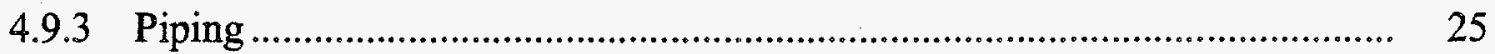

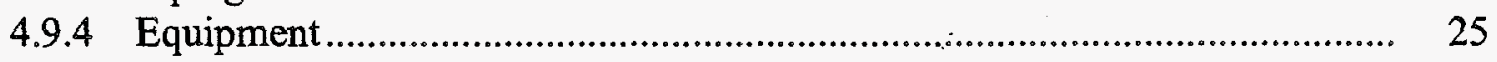

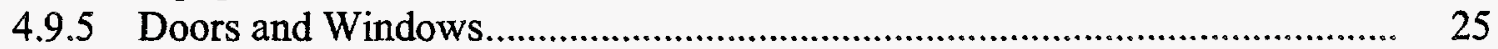

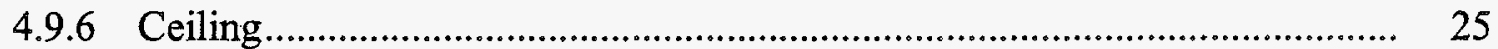

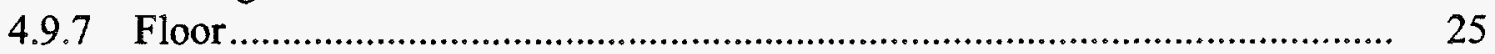

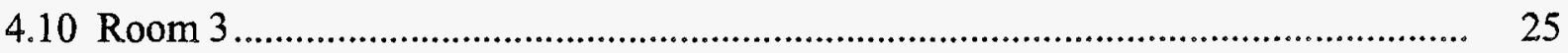

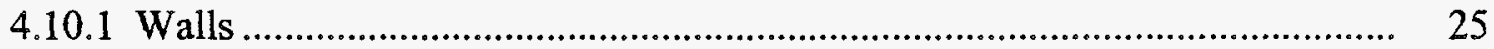

4.10.2 Finish Materials............................................................................. 26

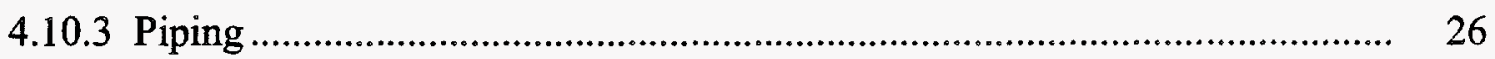

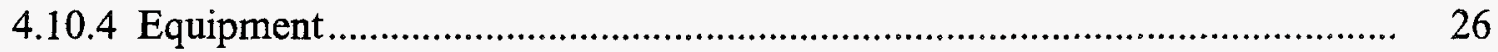

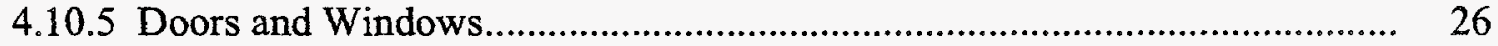

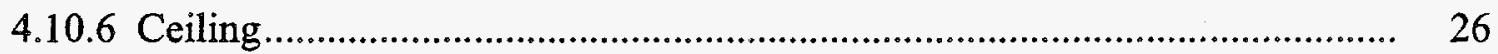

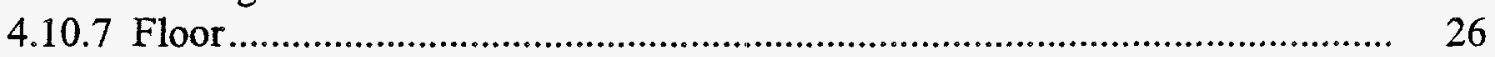

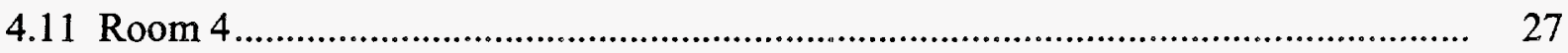

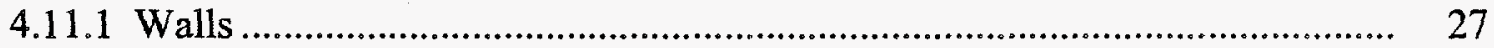

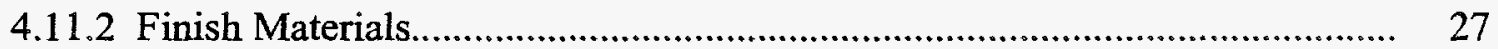

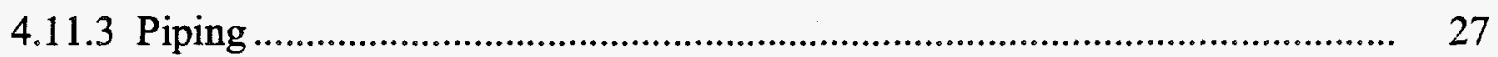

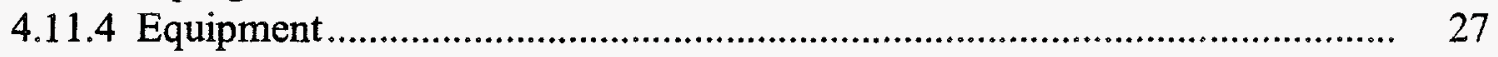

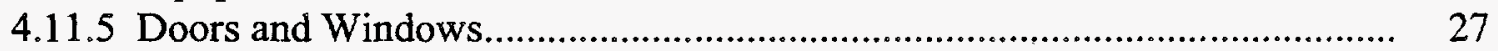

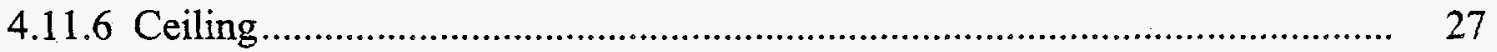

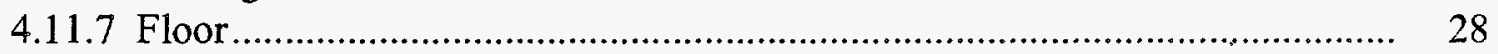

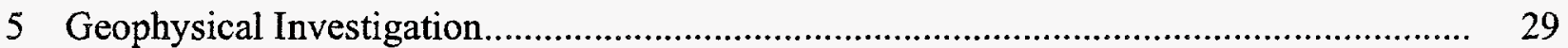

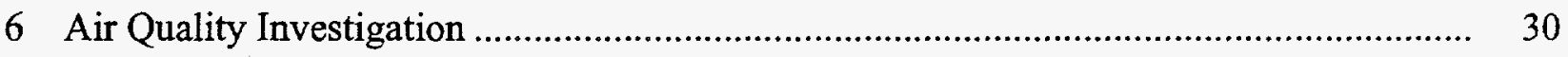

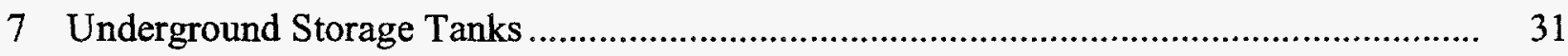

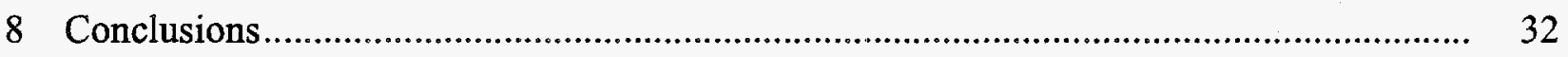

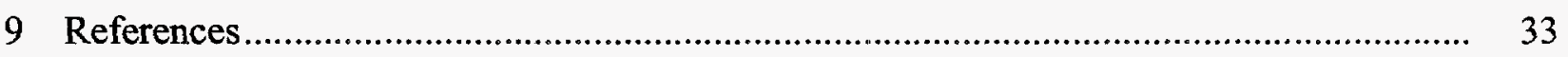

Appendix: Final Report - Environmental Geophysics: Building E3236

Decommissioning, Aberdeen Proving Ground. 


\section{Figures}

1 Map of Aberdeen Proving Ground Location .......................................................................... 4

2 Map of Building E3236 Location .................................................................................... 9

3 Building E3236 Floor Plan ......................................................................................... 10

4 Photographs of Building E3236 Exterior — North, East, and South Elevations ................ 11

5 Photographs of Building E3236 Exterior - West and North Elevations, West Roof, and Room 1 


\title{
Contamination Source Review for Building E3236, Edgewood Area, Aberdeen Proving Ground, Maryland
}

\author{
by \\ S. D. Zellmer, M.P. Smits, A.K. Draugelis, M.A. Glennon, \\ J. Rueda, and R.E. Zimmerman
}

\section{Summary}

This report was prepared by Argonne National Laboratory (ANL) to document the results of a contamination source review of Building E3236 at the Aberdeen Proving Ground (APG) in Maryland. The report may be used to assist the U.S. Army in planning for the future use or disposition of this building. The review included a historical records search, physical inspection, photographic documentation, geophysical investigation, and review of available records regarding underground storage tanks associated with Building E3236. The field investigations were performed by ANL during 1994.

Building E3236 (APG designation) is located south of South Kings Creek Road, east of the airstrip, and north of Beach Point Road in the Edgewood Area of APG. The original portion of Building E3236 was constructed in 1951 as an oil house, converted to a flammable storage facility in 1957, and used for that purpose until 1962. Potential contaminants used in the building include petroleum products and unidentified flammables. Alterations were made to the building during 1962 when it was converted to a non-human primate housing facility. The building was used to house primates until 1966, when more alterations and additions were made and the building was converted to a bioassay and animal experimentation laboratory in support of the botulinus toxin program. The facility was closed and the building decontaminated to a $3 \mathrm{X}$ condition in 1977 (this term is no longer a current, accurate term for decontamination of biological agents; the condition of the building in biological terms is unknown).

The physical inspection and photographic documentation of Building E3236 were completed in November 1994. Building E3236 is a four-room, single-story, L-shaped structure, consisting of the original 20 -ft by 20 -ft cinder block building, with a flat roof constructed of steel-reinforced concrete, and three additions. The additions are a cinder block room measuring $7 \mathrm{ft} 6$ in. by $8 \mathrm{ft}$ with a concrete roof (at the east end of the original building), a room measuring $10 \mathrm{ft}$ by $13 \mathrm{ft} 2 \mathrm{in}$. with wooden walls and roof (at the west end of the building), and a metal semi-trailer truck attached to the wooden addition.

At the time of the ANL inspection, a notice on the building warned of potential contamination, and no interior inspection or photographs could be completed except in the cinder block addition. Piping on the exterior and roof of the building is covered with suspected asbestos-containing insulation. 
During June 1994, ANL staff conducted geophysical surveys in the immediate vicinity of Building E3236 by using several nonintrusive methods. Survey results suggest the presence of some underground objects near Building E3236, but they do not provide conclusive evidence of the source of geophysical anomalies observed during the survey.

No information regarding air quality associated with Building E3236 is available because no air quality samples could be collected in the potentially contaminated building.

Historical documentation indicates that a liquid chemical waste drainage system in the building was formerly connected to a 275-gallon underground holding tank located south of the building. This tank was observed but not inspected or tested during the ANL field investigation. Historical documentation also indicates that a 2-in.-diameter sewer line and a 3-in.-diameter storm drain were associated with this building.

On the basis of information collected and reviewed by ANL for Building E3236, it is the authors' judgment that suspected asbestos-containing insulation on exterior piping warrants further investigation and evaluation. The 275-gallon underground holding tank that received laboratory waste may contain botulinus toxin solutions or other contaminants; additional sampling, analysis, and evaluation should be conducted. Results of the geophysical surveys indicate some anomalies near Building E3236 that warrant further investigation and evaluation. Notices posted on the building at the time of the ANL inspection indicated potential contamination of the building with petroleum products, unidentified flammables, and botulinus toxin solutions. A detailed investigation is needed to determine the type and degree of contamination in the building. Following this investigation, a complete inventory of the building interior should be conducted. 


\section{Introduction}

The U.S. Army Aberdeen Proving Ground (APG) commissioned Argonne National Laboratory (ANL) to conduct a contamination source review to identify and define areas of toxic or hazardous contaminants and to assess the physical condition and accessibility of APG buildings (Brubaker et al. 1994). The information obtained from the review may be used to assist the U.S. Army in planning for the future use or disposition of the buildings. The contamination source review consisted of the following tasks: historical records search, physical inspection, photographic documentation, geophysical investigation, and review of available records regarding underground storage tanks associated with each building. This report provides the results of the contamination source review for Building E3236.

Located on Chesapeake Bay in Harford and Baltimore counties, Maryland, APG occupies approximately 30,000 acres. The facility is divided into the Aberdeen and Edgewood areas (Figure 1). The primary mission at APG has been the testing and evaluation of U.S. Army warfare materials. Since its beginning in 1917, the Edgewood Area of APG has been the principal location for chemical warfare agent research, development, and testing in the United States. APG was also used for producing chemical warfare agents during both world wars and has been a center for the storage of chemical warfare material (Nemeth 1989).

Many of the APG facilities constructed between 1917 and the 1960s are no longer used because of obsolescence and their poor state of repair. Because many of these buildings were used for research, development, testing, and/or pilot-scale production of chemical warfare agents and other military substances (such as incendiary materials or munitions containing these materials), the potential exists for portions of the buildings to be contaminated with these substances, their degradation products, and other laboratory or industrial chemicals. These buildings and associated structures or appurtenances (e.g., underground or aboveground storage tanks, pipes, sumps) may contribute to environmental concerns at APG. 


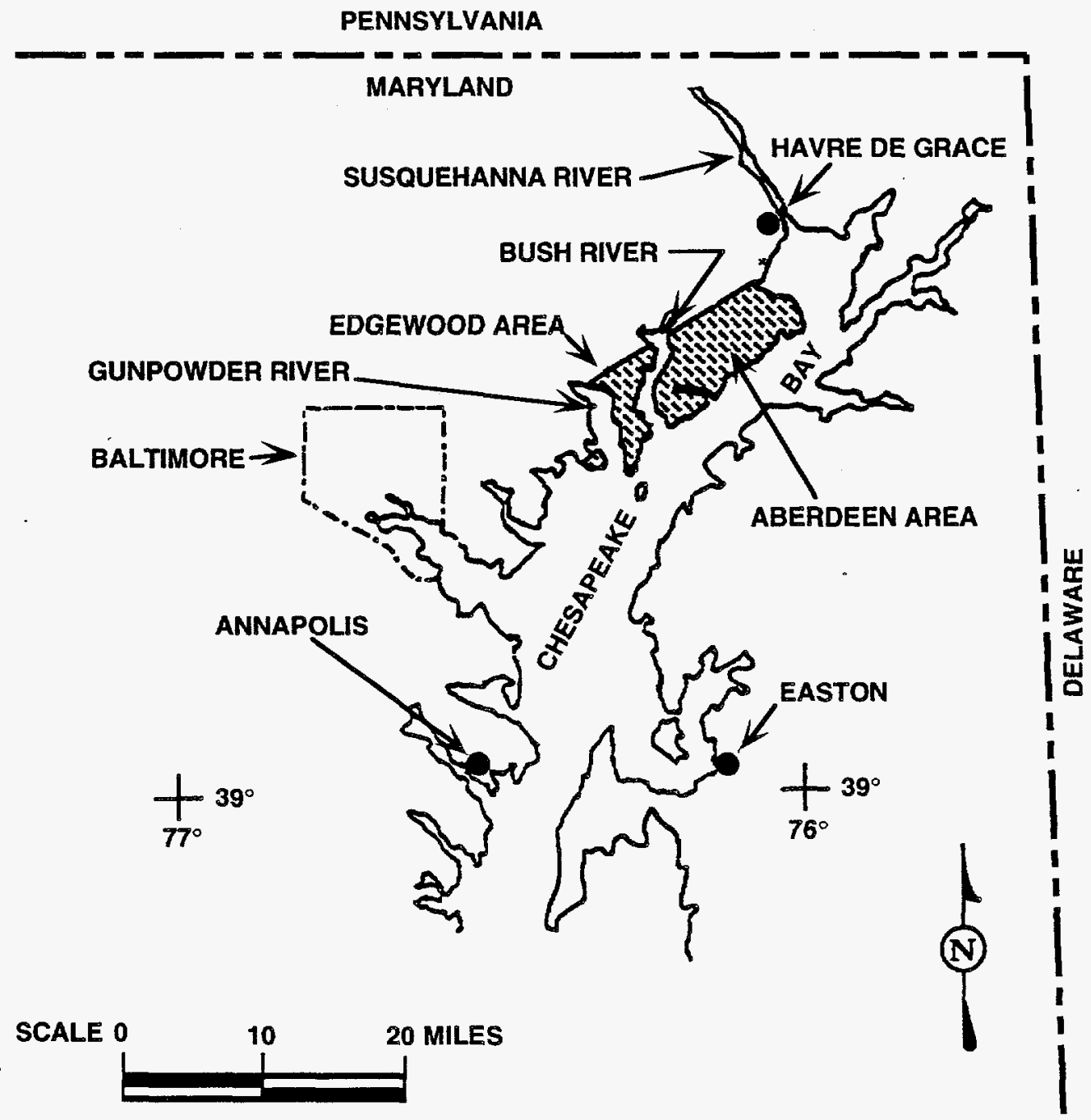

STI SHADED AREA INDICATES

ABERDEEN PROVING GROUND

FIGURE 1 Map of Aberdeen Proving Ground Location 


\section{Methodology}

Before the detailed building inspection, ANL personnel made a preliminary site visit to locate the building and obtain building records from APG, identify potential issues to be addressed in the health and safety plan, resolve any access restriction issues, and identify required support services.

Photographs were taken of the building's exterior surfaces during the inspection in November 1994. The photographs followed a set sequence whenever possible. The exterior was photographed starting on the north side and continuing clockwise around the building. No interior inspection was completed and no photographs were taken because the building was posted as containing potential contamination.

The area around Building E3236 was examined during the summer of 1994 using several nonintrusive geophysical survey methods, including total field magnetics, induced electromagnetic field (EMF), and ground-penetrating radar (GPR) techniques. A detailed description of the methodologies used for the geophysical investigation is provided in an appendix to this report. 


\section{Historical Record Search}

Building E3236 (APG designation) is located south of South Kings Creek Road, east of the airstrip, and north of Beach Point Road within APG's Edgewood Area. The building is near the southeast corner of the Building E32XX Medical Research Laboratories complex and was originally designated as Building 397 (Nemeth 1989).

The original portion of Building E3236 was constructed in 1951 as an oil house that measured $20 \mathrm{ft}$ by $20 \mathrm{ft}$, about $9 \mathrm{ft}$ high at the east end, and about $10 \mathrm{ft}$ high at the west end. Construction drawings show a concrete floor, cinder block walls, and a sloping, built-up, gravelfinish roof constructed over steel-reinforced concrete (APG drawing \#78-08-02, May 11, 1951). This drawing also shows racks for drums and shelving for oil storage. In 1957, the building was converted to a flammable storage facility and used for that purpose until 1962 (EAI Corporation 1989). Potential contaminants stored during this period included petroleum products and unidentified flammables. Alterations were made to the building in 1962, when the building was converted to a non-human primate housing facility; it was used for that purpose until 1966 (EAI Corporation 1989).

The building was again modified in 1966 and converted to a bioassay and animal experimentation laboratory in support of the botulinus toxin (XR) program. This conversion included installation of a bacteriological cabinet and filtered exhaust system. The cabinet contained a dry box, glove boxes, refrigerators, deep freeze, and autoclave. Originally, only solutions of XR were used in the facility. Later, because of the closure of Fort Detrick, other toxin materials were stored there (EAI Corporation 1989).

Three additions were made to the original building before it was closed in 1977: a 7-ft by 8 - $\mathrm{ft}$ cinder block addition at the east end of the original building, a 13-ft by $10-\mathrm{ft}$ wooden addition on the west end, and a 7 -ft-10-in. by 26 -ft metal semi-trailer truck addition attached to the wooden addition (real property record 1977 ). The real property record also indicated a 2-in.diameter sewer line and a 3-in.-diameter storm drain associated with the building (EAI Corporation 1989).

In 1977 the bioassay and animal experimentation laboratory were closed, and the building was decontaminated (EAI Corporation 1989). The decontamination procedure involved scrubbing the bacteriological cabinet, equipment, and working surfaces with diluted $(1 \%)$ sulfuric acid solution. Results of live animal testing conducted following decontamination revealed no botulinus (Standard Operating Procedure [SOP] No. 7-5-77-2 1977). This SOP indicated that the building had been decontaminated to a $3 \mathrm{X}$ condition, but this terminology is not a current, accurate term for the decontamination of biological agents. The biological contamination status of the building is therefore unknown.

Information provided by APG indicates that the drainage system in the building was surveyed some time after June 1979. A liquid chemical waste drainage system in the three laboratories, including the semi-trailer truck, was formerly connected to a 275 -gallon 
underground holding tank located south of the building. Dye-treated water used to trace the drainage system indicated that sinks in the main laboratory (original building) were connected to this underground holding tank. An anonymous, undated report refers to another document (Wastewater Treatment Facilities 1979), which revealed that the holding tank outlet had been plugged before the test. The dye-treated water test also showed that, because of a broken pipe, the floor drain in the semi-trailer truck laboratory had discharged onto the ground. The trench drain in the other laboratory could not be traced because the drain was blocked. 


\section{Building Description}

This section provides a physical description of Building E3236 and the surrounding site as they appeared during the ANL inspection in November 1994. This physical description includes an account of the condition of the exterior walls and roof of the building. At the time of the ANL inspection, the building was posted as potentially contaminated - preventing inspection of the building interior, with the exception of one room.

\subsection{Site Description}

\subsubsection{Location}

Building E3236 (APG designation) is located south of South Kings Creek Road, east of the airstrip, and north of Beach Point Road within APG's Edgewood Area (Figure 2).

\subsubsection{Proximity to Other Buildings}

The building is approximately $100 \mathrm{ft}$ east-northeast of Building E3265, near the southeast corner of the Building E32XX Medical Research Laboratories complex (Nemeth 1989).

\subsubsection{Building Structure}

Building E3236 is a four-room, single-story, L-shaped structure. The original building and one of the additions are constructed of 8 -in.-thick cinder block exterior walls and a steelreinforced concrete roof with a built-up, gravel finish. The west end of the building (second addition) is frame construction with wooden walls and a built-up, gravel finish roof over wood. A metal semi-trailer truck (third addition) is attached to the south side of the west addition to the building. Figure 3 shows the building floor plan and room number assignments developed during the ANL inspection and from historical documentation (EAI Corporation 1989). Figures 4 and 5 provide photographs of the exterior of the building.

\subsubsection{Exterior Dimensions}

North to south, the building measures $47 \mathrm{ft}$; east to west, it is $38 \mathrm{ft}$. The original building (room 2) is $20 \mathrm{ft}$ by $20 \mathrm{ft}$, about $9 \mathrm{ft}$ high at the north end, and $10 \mathrm{ft}$ high at the south end. The 


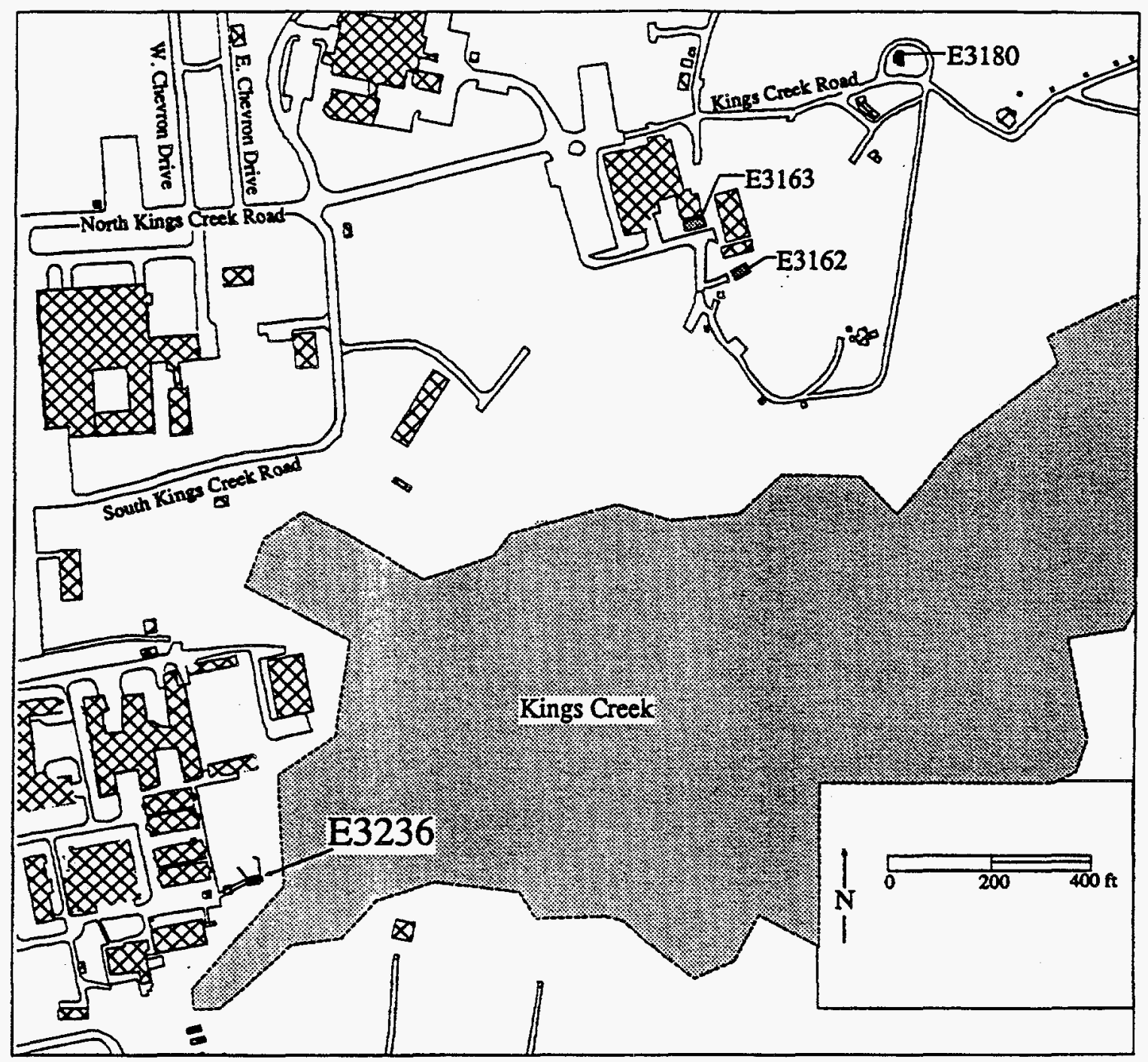

FIGURE 2 Map of Building E3236 Location 


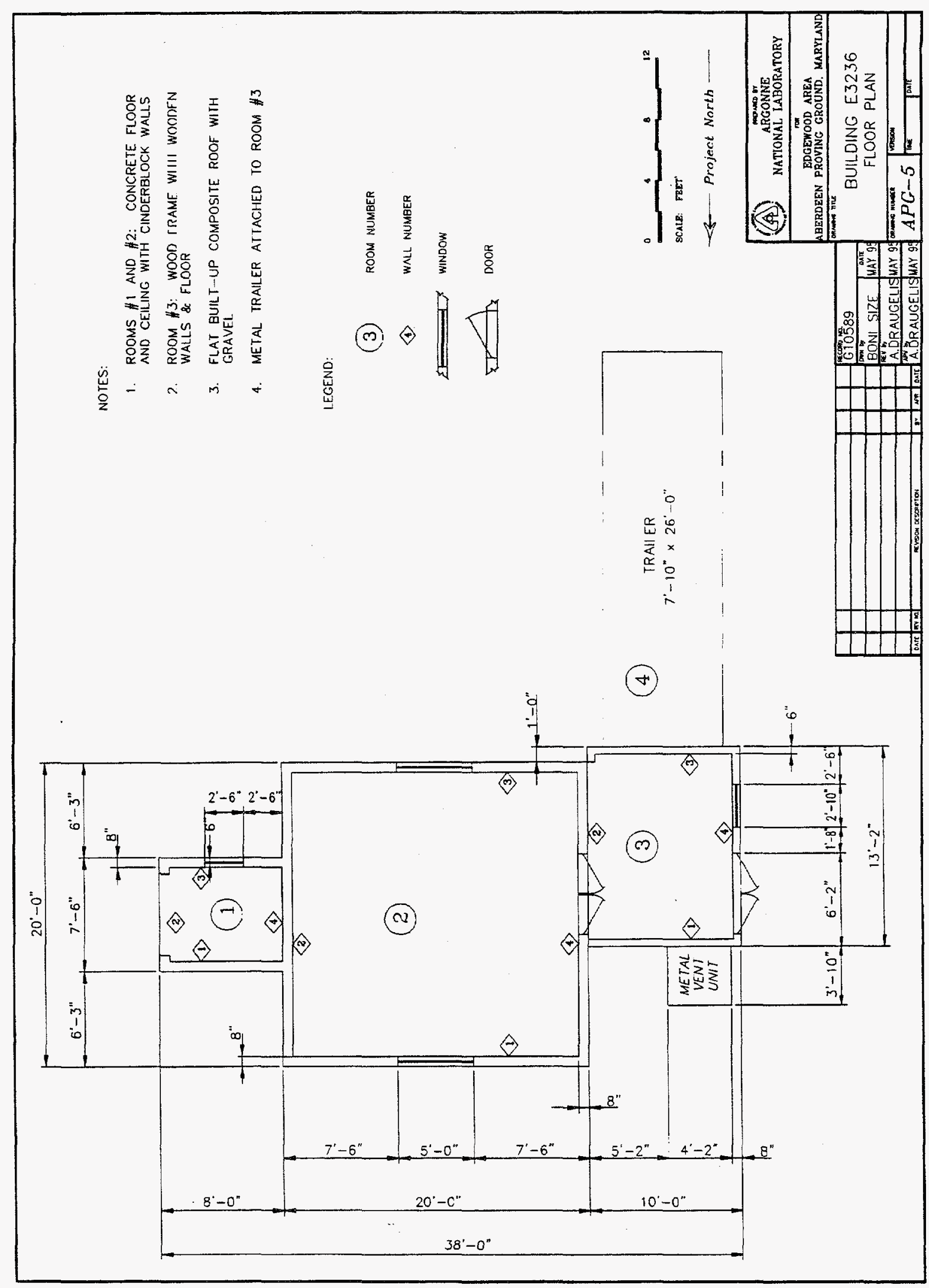

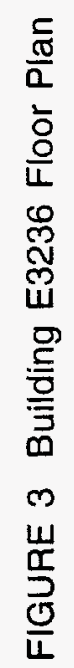



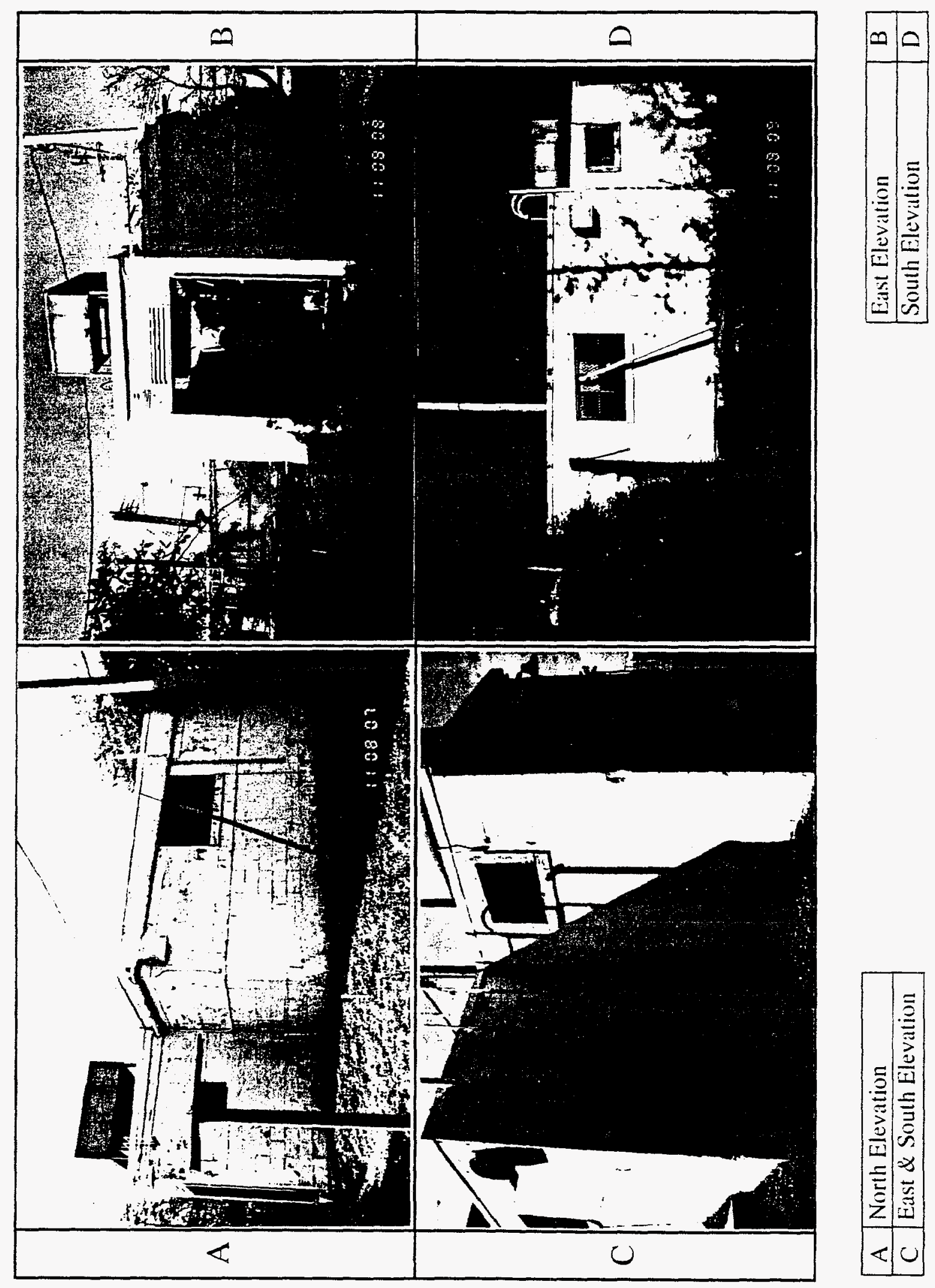

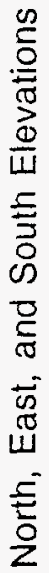



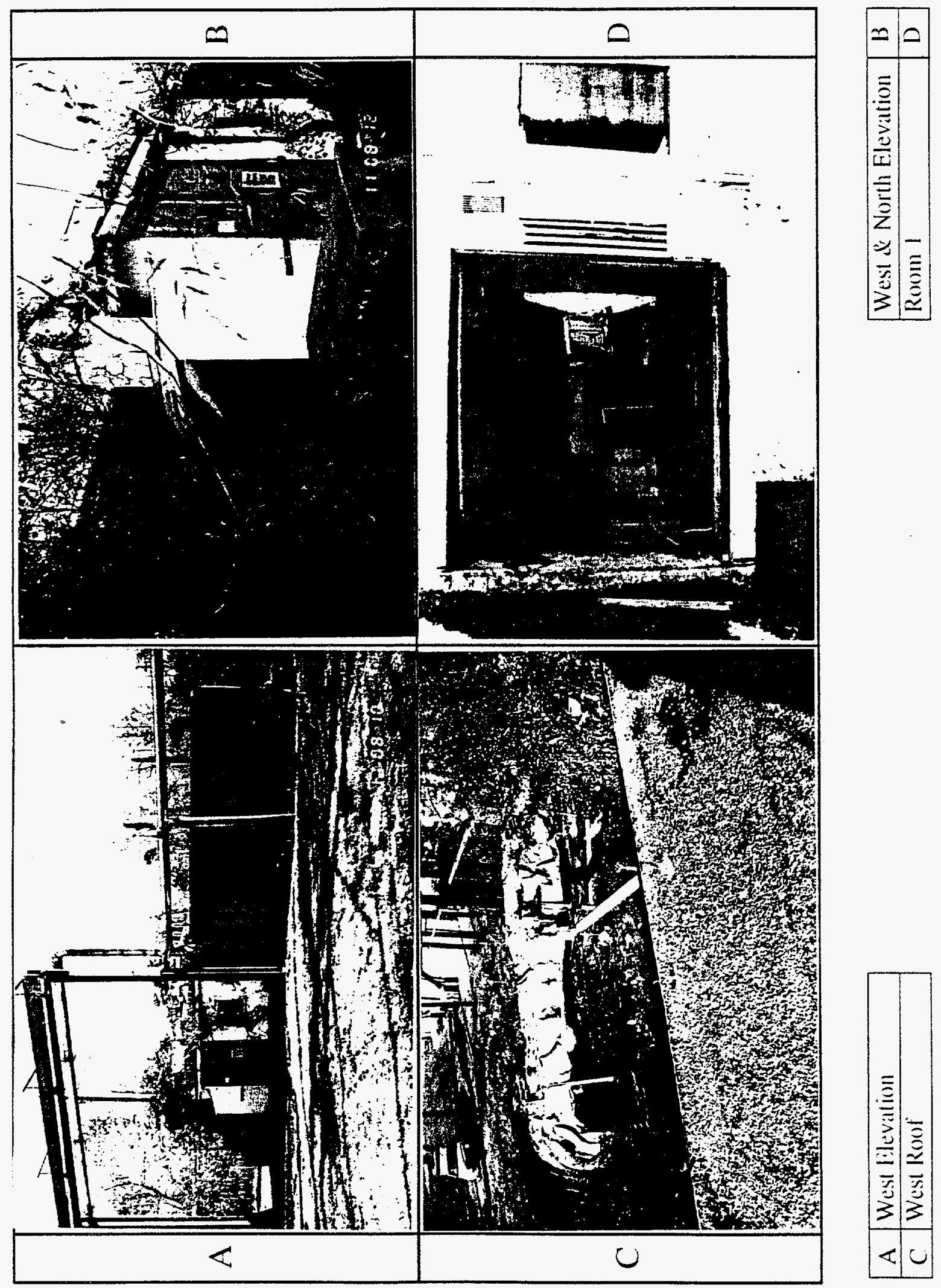

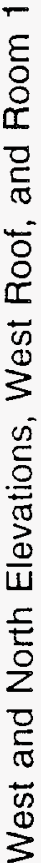

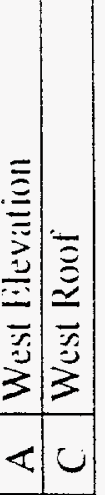


cinder block addition (room 1), centered on the east end of the original building, measures $7 \mathrm{ft} 6$ in. wide by $8 \mathrm{ft}$ long and about $9 \mathrm{ft}$ high. The wooden addition (room 3), at the southwest corner of the original building, is $10 \mathrm{ft}$ by $13 \mathrm{ft} 2 \mathrm{in}$. and about $8 \mathrm{ft}$ high. The semi-trailer truck addition (room 4), attached to the south side of the wooden addition, is $7 \mathrm{ft} 10 \mathrm{in}$. by $26 \mathrm{ft}$ and about $9 \mathrm{ft}$ high.

\subsubsection{Topography}

The area surrounding the building is relatively flat; surface drainage is to the southeast.

\subsubsection{Vegetation in the Immediate Vicinity}

The building is surrounded by cut vegetation (lawn) with trees and vines growing near the northwest corner of the building, at the southwest corner of the wooden addition (room 3), and along the northwest portion of the semi-trailer truck addition (room 4), and along the east side of the semi-trailer truck addition (Figures 4 and 5).

\subsubsection{External Aboveground Structures or Equipment}

An air conditioning condenser is mounted near the north end of the roof (room 1). A metal access ladder is attached to the east exterior wall of room 2 (Figure 4B). Ventilation duct work was observed on the roof of the wooden addition (room 3), at the west end of the building (Figure 5C). A metal vent is located near the south end of the roof of the semi-trailer truck addition (room 4) (Figure 5A), and metal ventilation ducts are located in the upper northeast and upper southeast corners of the original building (room 2).

\subsubsection{Connections with Adjacent Buildings}

None.

\subsubsection{Underground Structures}

A 275-gallon underground holding tank is reported to be located south of the original portion (room 2) of the building (EAI Corporation 1989). The building also reportedly contained a 3-in.-diameter storm drain and a 2-in.-diameter sewer line (EAI Corporation 1989). 


\subsubsection{Surface Drainage System}

None.

\subsubsection{Utility Access Points}

None.

\subsubsection{Exterior Piping}

A small-diameter pipe enters the north wall from the ground about $8 \mathrm{ft}$ from the northeast corner of the building (Figure 4A). A pipe covered with suspected asbestos-containing insulation extends just below the roof line along the north and east exterior walls of the building (Figure 4A). Vent pipes exit the north and east walls and extend above the roof (Figures 4A and 4B). Electrical conduit is also attached to the north and east exterior walls. A pipe exits through the window in the south wall and extends to a concrete platform adjacent to the south wall of the building; a second pipe on the south wall extends downward (Figure 4D). Another pipe covered with suspected asbestos-containing insulation extends down the west wall of the building (Figure 5A).

\subsubsection{Nearby Roads and Sidewalks}

An asphalt parking lot is west of the building, and a deteriorating asphalt driveway extends from the west doorway to the parking lot (Figures $5 \mathrm{~A}$ and $5 \mathrm{C}$ ).

\subsection{North Exterior Elevation}

\subsubsection{Dimensions}

The north exterior wall of the building is $38 \mathrm{ft}$ long. The cinder block addition (room 1) is $8 \mathrm{ft}$ long and about $9 \mathrm{ft}$ high. The original building (room 2) is $20 \mathrm{ft}$ long, about 9 high at the east end, and about $10 \mathrm{ft}$ high at the west end. The wooden addition (room 3 ) is $10 \mathrm{ft}$ long and about $9 \mathrm{ft}$ high. A 4-ft-2-in.-long metal ventilation unit shelter, extending $3 \mathrm{ft} 10 \mathrm{in}$. from the north wall, is located at the northwest corner of the building. 


\subsubsection{Construction Materials}

The exterior wall of the east portion of the building (rooms 1 and 2) is constructed of 8 -in.-thick cinder block; the exterior wall of the wooden addition (room 3) is supported by wood framing.

\subsubsection{Doors and Windows}

There are no doors in the north exterior wall. One window, measuring $5 \mathrm{ft}$ by $2 \mathrm{ft} 9 \mathrm{in}$., is located $15 \mathrm{ft} 6$ in. from the northeast corner of the building. The window has six glass panes with a metal screen over the glass.

\subsubsection{Piping}

A small-diameter pipe enters the north wall from the ground about $8 \mathrm{ft}$ from the northeast corner. A pipe covered with suspected asbestos-containing insulation is located just below the roof line on the north exterior wall. A vent pipe, located about $1 \mathrm{ft}$ west of the window, extends above the roof; electrical conduit is attached to the north exterior wall.

\subsubsection{Utility Connections}

None.

\subsubsection{External Equipment or Structures}

An exterior light is attached to the northeast corner of the north exterior wall. A second exterior light (with switch) is on the north wall at the northeast corner of the original building (room 2). A metal ventilation duct also is located in the upper northeast corner of the original building (room 2). ANL observed a metal ventilation unit shelter, $4 \mathrm{ft} 2 \mathrm{in}$. long and extending $3 \mathrm{ft} 10 \mathrm{in}$. from the north wall, at the northwest corner of the building. Metal ventilation duct work extends from the roof of the shelter onto the roof of the building (Figure 5B).

\subsubsection{Vegetation}

The area north of the building is cut vegetation (lawn) with trees and vines growing near the northwest corner of the building. 


\subsubsection{Overall Condition}

The north side of the building is in good condition but shows signs of weathering.

\subsection{East Exterior Elevation}

\subsubsection{Dimensions}

The overall length of the east building exterior is $47 \mathrm{ft}$. The east exterior of the original building is $20 \mathrm{ft}$ long and about $9 \mathrm{ft}$ high. The cinder block addition (room 1) is $7 \mathrm{ft} 6 \mathrm{in}$. long, about $9 \mathrm{ft}$ high, and extends east $8 \mathrm{ft}$ from the building (room 2). The wooden addition (room 3 ) extends about $1 \mathrm{ft}$ south of the original building, with a height of about $9 \mathrm{ft}$. The length of the semi-trailer truck addition (room 4), attached to the south side of the wooden addition, is $26 \mathrm{ft}$.

\subsubsection{Construction Materials}

The exterior walls of the original building and of room 1 are 8 -in.-thick cinder block. The walls of the wooden addition (room 3) are wood and the semi-trailer truck addition wall is constructed of metal.

\subsubsection{Doors and Windows}

A 6-ft by 7-ft doorway is in the center of the east exterior, with two louvered vents above the doorway. There are no windows.

\subsubsection{Piping}

A pipe covered with suspected asbestos-containing insulation is below the roof line on the north one-third of the building. A pipe vent exits the wall near the southeast corner of the building and extends above the roof. Electrical conduits are also attached to the east exterior wall.

\subsubsection{Utility Connections}

None. 


\subsubsection{External Equipment or Structures}

A metal ladder leading to the building roof is attached to the east exterior wall near the south side of the cinder block addition (room 1).

\subsubsection{Vegetation}

The area east of the building is cut vegetation (lawn). There are trees growing along the northern part of the east side of the semi-trailer truck addition (room 4).

\subsubsection{Overall Condition}

The east elevation of the building is in good condition but shows signs of weathering. The semi-trailer truck addition is rusted.

\subsection{South Exterior Elevation}

\subsubsection{Dimensions}

The south exterior wall of the building is $38 \mathrm{ft}$ long. The cinder block addition (room 1) is $8 \mathrm{ft}$ long and about $9 \mathrm{ft}$ high. The original building (room 2) is $20 \mathrm{ft}$ long, about 9 high at the east end, and about $10 \mathrm{ft}$ high at the west end. The wooden addition (room 3 ) is $10 \mathrm{ft}$ long and about $9 \mathrm{ft}$ high. The semi-trailer truck, attached to the center of the south side of the wooden addition, is $7 \mathrm{ft} 10$ in. wide and about $9 \mathrm{ft}$ high.

\subsubsection{Construction Materials}

The exterior walls of rooms 1 and 2 are 8 -in.-thick cinder block. The exterior walls of room 3 are wood supported by wood framing. The semi-trailer truck addition is constructed of metal.

\subsubsection{Doors and Windows}

There are two windows in the south exterior wall. One, measuring $2 \mathrm{ft} 6 \mathrm{in}$. by $2 \mathrm{ft}$ and containing no glass, is about $3 \mathrm{ft}$ from the northeast corner of the building (in room 1). A second, 
measuring $5 \mathrm{ft}$ by $2 \mathrm{ft} 9 \mathrm{in}$., is $15 \mathrm{ft} 6 \mathrm{in}$. from the northeast corner of the building (in room 2). This window has six glass panes with a metal screen over the glass. There are no doors on the south elevation.

\subsubsection{Piping}

A pipe exits the window in room 2 and extends to a concrete platform adjacent to the south wall of the building. A second pipe exits the south wall and extends downward about $2 \mathrm{ft} 6$ in.

\subsubsection{Utility Connections}

None.

\subsubsection{External Equipment or Structures}

A metal ventilation duct is located in the upper southeast corner of the original building (room 2).

\subsubsection{Vegetation}

The area south of the building is cut vegetation (lawn). Trees are growing along the northern part of the east side of the semi-trailer truck addition (room 4).

\subsubsection{Overall Condition}

The south exterior wall of the building is in good condition but shows signs of weathering. The semi-trailer truck addition is rusted. 


\subsection{West Exterior Elevation}

\subsubsection{Dimensions}

The overall length of the west exterior wall is about $47 \mathrm{ft}$. The north $8 \mathrm{ft}$ of the west exterior is the original building (room 2) and measures about $10 \mathrm{ft}$ high. The wooden addition (room 3) is about $13 \mathrm{ft}$ long and about $9 \mathrm{ft}$ high. The length of semi-trailer truck addition (room 4) is $26 \mathrm{ft}$. A metal ventilation unit shelter measuring $3 \mathrm{ft} 10 \mathrm{in}$. is located at the northwest corner of the wooden addition (room 3 ).

\subsubsection{Construction Materials}

The west exterior wall of the original building is constructed of 8 -in.-thick cinder block. The wall of room 3 is wood supported by wooden framing. The ventilation shelter and semitrailer truck are metal.

\subsubsection{Doors and Windows}

There are one window and one doorway in the west exterior wall of the building. The window is approximately $3 \mathrm{ft}$ square, contains six glass panes, and is located $2 \mathrm{ft} 6 \mathrm{in}$. from the southwest corner of the wooden addition (room 2). The doorway, measuring $6 \mathrm{ft} 2 \mathrm{in}$. wide by $7 \mathrm{ft}$ high with two wood doors and a single glass window in each door, is at the northwest corner of the wooden addition (room 2). This doorway, the only entrance to rooms 2,3 , and 4, was barred at the time of the ANL inspection. A sign, indicating that the building contained potential contamination, was posted on the door.

\subsubsection{Piping}

A pipe covered with suspected asbestos-containing insulation extends from the roof almost to the ground on the north side of the window in the building's west wall.

\subsubsection{Utility Connections}

None. 


\subsubsection{External Equipment or Structures}

A metal ventilation unit shelter ( $3 \mathrm{ft} 10 \mathrm{in}$. by $4 \mathrm{ft} 2 \mathrm{in}$.) is located at the northwest corner of the wooden addition (room 3). Ventilation duct work from this shelter extends over and into the roof near the south end of the wooden addition (room 3 ).

\subsubsection{Vegetation}

The area west of the building is cut vegetation (lawn) with vines and trees growing near the intersection of the wooden addition (room 3) and the semi-trailer truck (room 4).

\subsubsection{Overall Condition}

The west elevation of the building is in good condition but shows signs of weathering. The semi-trailer truck is rusted.

\subsection{Roof}

\subsubsection{Type and Dimensions}

The building has a flat roof. The roof of the original building (room 2) is $20 \mathrm{ft}$ by $20 \mathrm{ft}$, the cinder block addition (room 1) roof is $7 \mathrm{ft} 6 \mathrm{in}$. by $8 \mathrm{ft}$, the wooden addition (room 3) roof is about $13 \mathrm{ft}$ by $10 \mathrm{ft}$, and the semi-trailer truck addition (room 4) roof measures $10 \mathrm{ft} 7 \mathrm{in}$. by $26 \mathrm{ft}$ (Figure 3).

\subsubsection{Height}

The height of the roof of the original building (room 2) is about $9 \mathrm{ft}$ at the north end and about $10 \mathrm{ft}$ at the south end. The roof height of the cinder block addition (room 1), the wooden addition (room 3), and the semi-trailer truck addition (room 4) is about $9 \mathrm{ft}$. 


\subsubsection{Surface Materials}

The original building (room 2), the cinder block addition (room 1), and wooden addition (room 3) have a built-up, gravel-finish roof. The semi-trailer truck addition (room 4) has a metal roof.

\subsubsection{Support System}

The roof on the original building (room 2) and the cinder block addition (room 1), is constructed of reinforced concrete supported by the exterior building walls. The roofs of the wooden addition (room 3) and the semi-trailer truck addition (room 4) are wood and metal, respectively, but the support systems for these two additions could not be determined.

\subsubsection{Condition}

The roof of the building appeared to be in good condition with the exception of the wooden addition (room 3) roof, which has deteriorated; several holes were observed in this roof.

\subsubsection{Equipment Located on Roof}

An air conditioning condenser is mounted near the north end of the roof (room 1). Ventilation duct work is located on the roof of the wooden addition (room 3) at the west end of the building (Figure 4C).

\subsubsection{Chimneys, Roof Vents, or Vent Stacks}

A sheet-metal vent was observed near the south end of the roof of the semi-trailer truck addition (room 4).

\subsubsection{Piping}

A pipe covered with suspected asbestos-containing insulation runs from the original building (room 2) to the ventilation duct work on the roof of the wooden addition (room 3 ) (Figure 4C). 


\subsection{Interior Floor Plan}

\subsubsection{Room Numbers and Dimensions}

The building contains four rooms; the dimensions of the rooms, except room 2, were determined by exterior measures and historical documentation because the building was inaccessible when the ANL inspection was completed. The assumed dimensions of the individual rooms are as follows:

- Room 1, about $6 \mathrm{ft} 4$ in. by $7 \mathrm{ft} 4$ in.;

- Room 2, about $18 \mathrm{ft} 8$ in. by $18 \mathrm{ft} 8$ in.;

- Room 3, about $9 \mathrm{ft} 6$ in. by $12 \mathrm{ft} 2$ in.; and

- Room 4, about $7 \mathrm{ft} 6$ in. by $25 \mathrm{ft} 8 \mathrm{in}$.

Figure 3 shows the floor plan and room number assignments developed during the ANL investigation and from historic documentation.

\subsubsection{Walls}

The perimeter walls of the cinder block addition (room 1) are constructed of 8-in.-thick cinder blocks. The construction materials for the other perimeter walls, determined from historic documentation and exterior examination, are as follows:

- Original building (room 2), 8-in.-thick cinder blocks;

- Wooden addition (room 3), wood supported by wood framing; and

- Semi-trailer truck addition (room 4), metal.

\subsubsection{Floor}

The floor of the cinder block addition (rooms 1) is concrete. On the basis of historic documentation, the floor of the original building (room 2) is also concrete. Inspection of rooms 3 and 4 was not possible, so the type of floor materials is unknown. 


\subsubsection{Floor Penetrations}

No floor penetrations were observed in room 1. Inspection of the other rooms was not possible, so the type and number of floor penetrations are unknown.

\subsubsection{Interior Partitions}

No interior partitions are present in room 1 . Inspection of the other rooms was not possible, so the type and number of interior partitions are unknown.

\subsubsection{Equipment or Supplies}

Room 1 contains an air conditioning compressor, associated piping, and electrical connections and conduits. Inspection of the other rooms was not possible, so the presence of equipment or supplies is unknown.

\subsection{Room 1}

\subsubsection{Walls}

The walls of room 1 are constructed of 8-in.-thick cinder blocks.

\subsubsection{Finish Materials}

The cinder block walls are unpainted.

\subsubsection{Piping}

Piping covered with suspected asbestos-containing insulation is associated with the ventilation system. 


\subsubsection{Equipment}

Ventilation equipment, air conditioning compressor and associated piping, and electrical connection and conduits were observed in room 1 .

\subsubsection{Doors and Windows}

A 6- $\mathrm{ft}$ by 7-ft doorway, without doors, is located in the center of the east wall. Two louvered vents are above the doorway. The south wall of room 1 contains a window measuring $2 \mathrm{ft} 6 \mathrm{in}$. by $2 \mathrm{ft}$ that contains no glass and is located about $3 \mathrm{ft}$ from the southeast corner of the room.

\subsubsection{Ceiling}

The ceiling in room 1 is constructed of reinforced concrete.

\subsubsection{Floor}

The floor in room 1 is constructed of concrete.

\subsection{Room 2}

No inspection or photographs were made of the room 2 (original building) interior because this room was posted as containing potential contamination. Information provided here was developed from an external inspection and historical documentation.

\subsubsection{Walls}

The walls in room 2 are constructed of 8 -in.-thick cinder blocks.

\subsubsection{Finish Materials}

Unknown. 


\subsubsection{Piping}

Unknown.

\subsubsection{Equipment}

Unknown.

\subsubsection{Doors and Windows}

Room 2 has one doorway and two windows. A 6-ft-2-in.-wide by 7-ft-high doorway occupies the center of the west wall (wall 4) according to historical documentation. Two windows, each measuring $5 \mathrm{ft}$ wide by $2 \mathrm{ft} 9 \mathrm{in}$. high, are located $7 \mathrm{ft} 6 \mathrm{in}$. from the east wall in the north and south walls. Both windows have six glass panes with a metal screen outside the glass.

\subsubsection{Ceiling}

The ceiling of room 2 is constructed of reinforced concrete.

\subsubsection{Floor}

The floor in room 2 is constructed of concrete.

\subsection{Room 3}

No inspection or photographs were made of the room 3 (wooden addition) interior because this room was posted as containing potential contamination. Information provided here was developed from an external inspection and historical documentation.

\subsubsection{Walls}

The east wall (wall 2) is constructed of 8-in.-thick cinder blocks; the other walls are wood. 


\subsubsection{Finish Materials}

Unknown.

\subsubsection{Piping}

Unknown.

\subsubsection{Equipment}

Unknown.

\subsubsection{Doors and Windows}

One window and probably three doors are located in room 3. According to historical documentation, a 6-ft-2-in.-wide by 7-ft-high doorway located in the east wall (wall 2), in the northeast comer of the room, provides access to room 2. There is likely a doorway in wall 3 to provide access to the semi-trailer truck addition (room 4). A 6-ft-2-in.-wide by 7-ft-high doorway with two wood doors and a single glass window in each door is at the northwest corner of wall 4, providing the only access to the building exterior. The window, approximately $3 \mathrm{ft}$ square with six glass panes, is on the west wall (wall 4), about $2 \mathrm{ft} 6 \mathrm{in}$. from the southwest corner of the room.

\subsubsection{Ceiling}

The ceiling in room 3 is probably constructed of wood.

\subsubsection{Floor}

Unknown. 


\subsection{Room 4}

No inspection or photographs were made of the room 4 (semi-trailer truck addition) interior because this room was posted as containing potential contamination. Information provided here was developed from an external inspection and historical documentation.

\subsubsection{Walls}

The walls of room 4 are probably metal.

\subsubsection{Finish Materials}

Unknown.

\subsubsection{Piping}

Unknown.

\subsubsection{Equipment}

Unknown.

\subsubsection{Doors and Windows}

Room 4 probably contains one door and no windows. A doorway in the north wall (back end) of the semi-trailer truck addition probably provides access to the room.

\subsubsection{Ceiling}

The ceiling of room 4 is probably constructed of metal. 
4.11.7 Floor

Unknown. 


\section{Geophysical Investigation}

ANL geophysical staff surveyed the area around Building E3236 during June 1994. Nonintrusive methods used for the surveys were total field magnetics, induced electromagnetic field (EMF), and ground-penetrating-radar (GPR) techniques.

Geophysical anomalies were detected near Building E3236, overhead pipes, and metal fences at the site, but the sources of these anomalies were obscured by interference caused by the aboveground structures. A linear anomaly about $25 \mathrm{ft}$ west of the building extends northward from the mid-point of the semi-trailer truck addition to the northern limit of the survey area. The probable source of this anomaly is a buried pipe or utility line. GPR data along this line suggest that this feature is shallowly buried. Other GPR anomalies were detected in a band starting at a point about $12 \mathrm{ft}$ southwest of the southwest corner of the semi-trailer truck addition and extending westward along a metal fence. These anomalies were distinct from the fence and suggest anthropogenic sources. EMF and magnetic anomalies were also present in this area, but interpretation was obscured by interference from the metal fence. Other isolated magnetic, EMF, and GPR anomalies were detected at the site but were not spatially associated; their sources are unknown.

The geophysical surveys suggest the presence of some underground objects near Building E3236 but do not provide conclusive evidence of the sources of the anomalies detected. The preliminary geophysical report for Building E3236 is proved as an appendix to this document. 


\section{Air Quality Investigation}

Information on air quality associated with Building E3236 is not available; no air sampling was conducted because a notice posted on the building stated that potential contamination was present. 


\section{Underground Storage Tanks}

Historical documentation indicates that a liquid chemical waste drainage system in the three laboratories, including the semi-trailer truck, was formerly connected to a 275 -gallon underground holding tank located south of the building (EAI Corporation 1989). Historical documentation also indicates that a 2-in.-diameter sewer line and a 3-in.-diameter storm drain were associated with this building (EAI Corporation 1989). 


\section{Conclusions}

On the basis of information collected and reviewed by ANL for Building E3236, it is the authors' judgment that suspected asbestos-containing insulation on the exterior piping warrants further investigation and evaluation. The 275-gallon underground holding tank located south of the building that received laboratory waste may contain botulinus toxin solutions or other contaminants, indicating the need for additional sampling, analysis and evaluation. Results of the geophysical surveys indicate some anomalies near Building E3236; further investigation and evaluation are needed to identify the sources of these anomalies. Building E3236 was posted as containing potential contamination at the time of the ANL inspection. Potential contaminants include petroleum products, unidentified flammables, and botulinus toxin solutions. A detailed investigation is needed to determine the type and degree of contamination in the building. Following this investigation, a complete inventory of the building interior should be conducted. 


\section{References}

Brubaker, K.L., J.M. Dougherty, and L.D. McGinnis, 1994, Initial Building Investigation at Aberdeen Proving Ground, Maryland: Objectives and Methodology, ANL/ESD/TM-61, Argonne National Laboratory, Argonne, Ill.

EAI Corporation, 1989, Historical Records Search and Site Survey of the Edgewood Area Building - Final Report, prepared for U.S. Army Chemical Research, Development, and Engineering Center, Aberdeen Proving Ground, Maryland, under contract no. DAAIS-87-D0021.

Nemeth, G., 1989, RCRA Facility Assessment Report, Edgewood Area, Aberdeen Proving Ground, Maryland, unnumbered report prepared for Aberdeen Proving Ground, Maryland.

Real Property Record, 1977, SMUEA Form 8-4 Note, March 21.

SOP No. 7-5-77-2, 1977, Standard Operating Procedure, Decontamination of Building E3236, Aug. 3.

Wastewater Treatment Facilities, Edgewood Area Plant, 1979, Drawing Number 26-12-32, Sheet Number 322, Microfilm A34634, June. 
Appendix:

Final Report - Environmental Geophysics:

Building E3236 Decommissioning, Aberdeen Proving Ground 


\title{
Final Report - \\ Environmental Geophysics: \\ Building E3236 Decommissioning, Aberdeen Proving Ground
}

\author{
Prepared by \\ M.A. Glennon, G.J. Keucher, \\ M.D. Thompson, C.R. Daudt, M.A. Benson, and J.E. Stefanov
}

Center for Environmental Restoration Systems

Energy Systems Division

Argonne National Laboratory

9700 South Cass Avenue

Argonne, IL 60439

July 1995

Work sponsored by

United States Army, Aberdeen Proving Ground, Maryland 


\section{Contents}

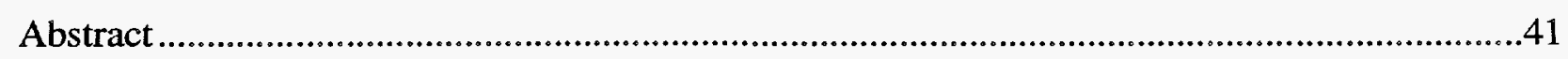

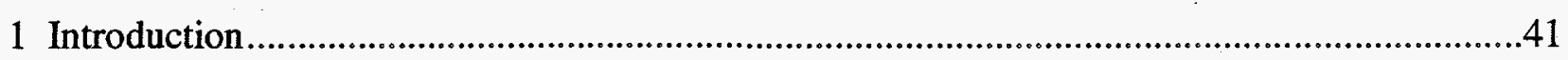

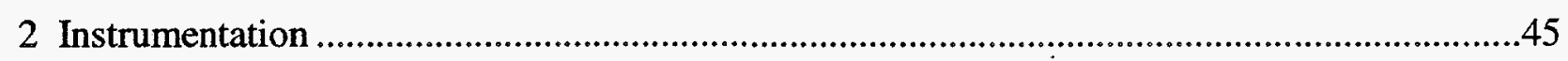

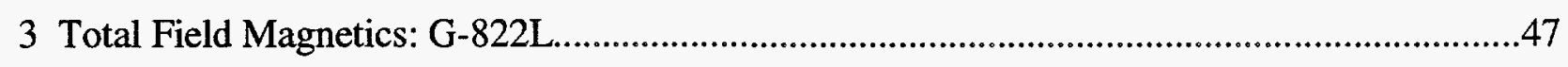

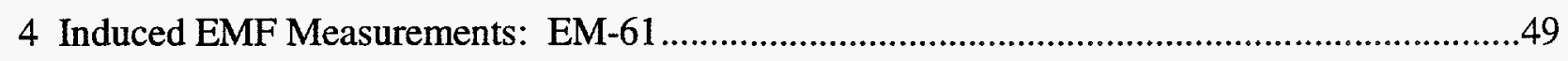

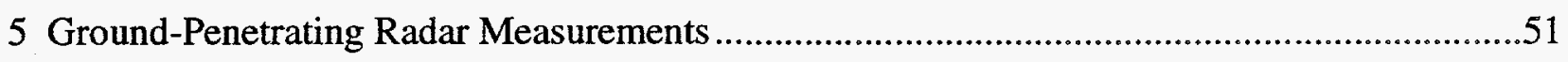

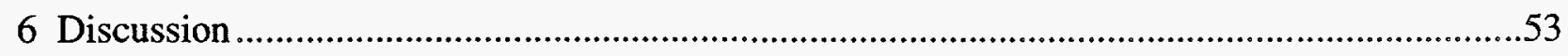

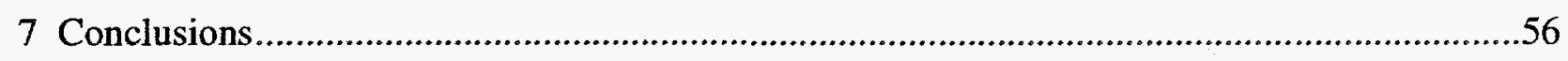

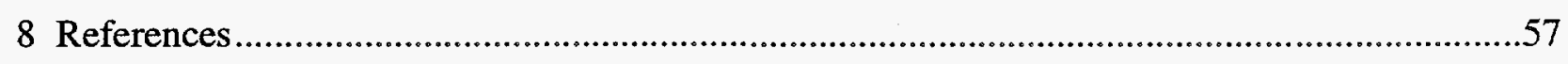

\section{Tables}

1 Location and Description of Geophysical Anomalies Detected near Building E3236.

Figures

1 General Site Map of the Kings Creek Area, Aberdeen Proving Ground, MD.........................42

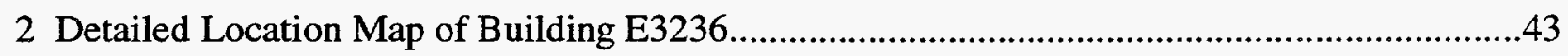

3 Map of GPR Transects Conducted Near Building E3236 ................................................46

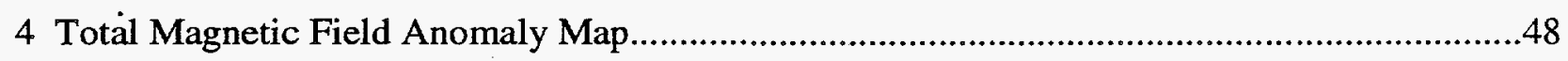

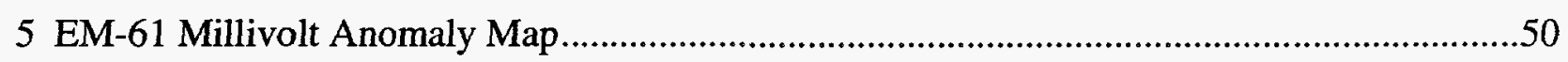

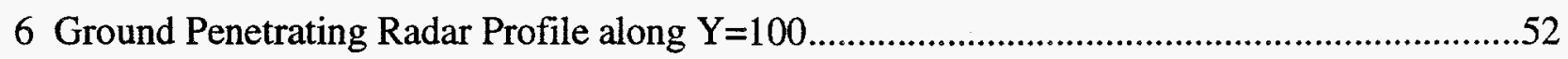

7 EM-61 Millivolt Anomaly Map with Overlay of Magnetic Field Contours ..........................54 


\title{
Final Report - Environmental Geophysics: Building E3236 Decommissioning, Aberdeen Proving Ground
}

\begin{abstract}
The immediate vicinity surrounding Building E3236 and associated trailer, a potentially contaminated site in the Kings Creek area of Aberdeen Proving Ground, was examined using several nonintrusive, geophysical surveys, including total-field magnetic, time-domain electrical induction (EMF or EM-61), and ground-penetrating radar (GPR) techniques. A linear EMF anomaly along $X=120$ was also detected as isolated magnetic and GPR anomalies and is probably sourced by a buried utility. Magnetic and EMF anomalies surround the building, metal fences, and the footings for overhead pipe works. GPR transects along the southern boundary suggest the presence of buried material. The sources of the few isolated EMF, magnetic, and GPR anomalies are unknown.
\end{abstract}

\section{Introduction}

Environmental geophysics studies have been conducted at Building E3236 and trailer, located in the Kings Creek Area, Aberdeen Proving Ground (Figure 1). These studies were conducted by ANL staff in mid-June 1994.

Building E3236 is located south of South Kings Creek Road (Figure 1). According to building records examined by EAI Corporation (1989), the structures have the following history. Construction began in 1951, and Building E3236 was operated as an oil house (storage) from 1951 to 1957 . From 1957 to 1962 , it was used to store flammables. From 1962 to 1966 , it was operated as a housing for non-human primates, and as a bioassay and animal experimentation laboratory from 1966 to 1977 . The RCRA Facility Assessment Report (1989) indicated that an incinerator for pathological/infectious wastes was operated at this site. Activities at the building ceased in 1977, and the building has remained unoccupied till the present day.

The building is constructed on a $20 \times 20 \mathrm{ft}$ concrete floor, and has several additions measuring $7 \times 8 \mathrm{ft}, 13 \times 9 \mathrm{ft}$, and $8 \times 27 \mathrm{ft}$. The walls are made of 8 -in. concrete blocks with 4-in. plywood, and the roof consists of concrete and 5-ply built-up. The ventilation system consists of one air handling unit (model \#C163.06). The drainage system consists of one 3 -in. storm drain (domestic), one 2-in. sewer line, and one 2-in. chemical drain feeding into a 275 -gal holding tank (EAI Corp. 1989).

Possible contaminants are unknown petroleum products, flammables, and solutions of botulinus toxins. The building was apparently decontaminated in 1977 to a " $3 X$ " condition. Other possibilities for contamination are unknown. The 1989 U.S. Army Environmental Hygiene Agency report states that the chemical/storm drains discharged to ditches and the marsh associated with Kings Creek at the locations immediately northeast, east, and southeast of the building complexes (Figure 2). There have been no non-storm water discharges to the Kings 


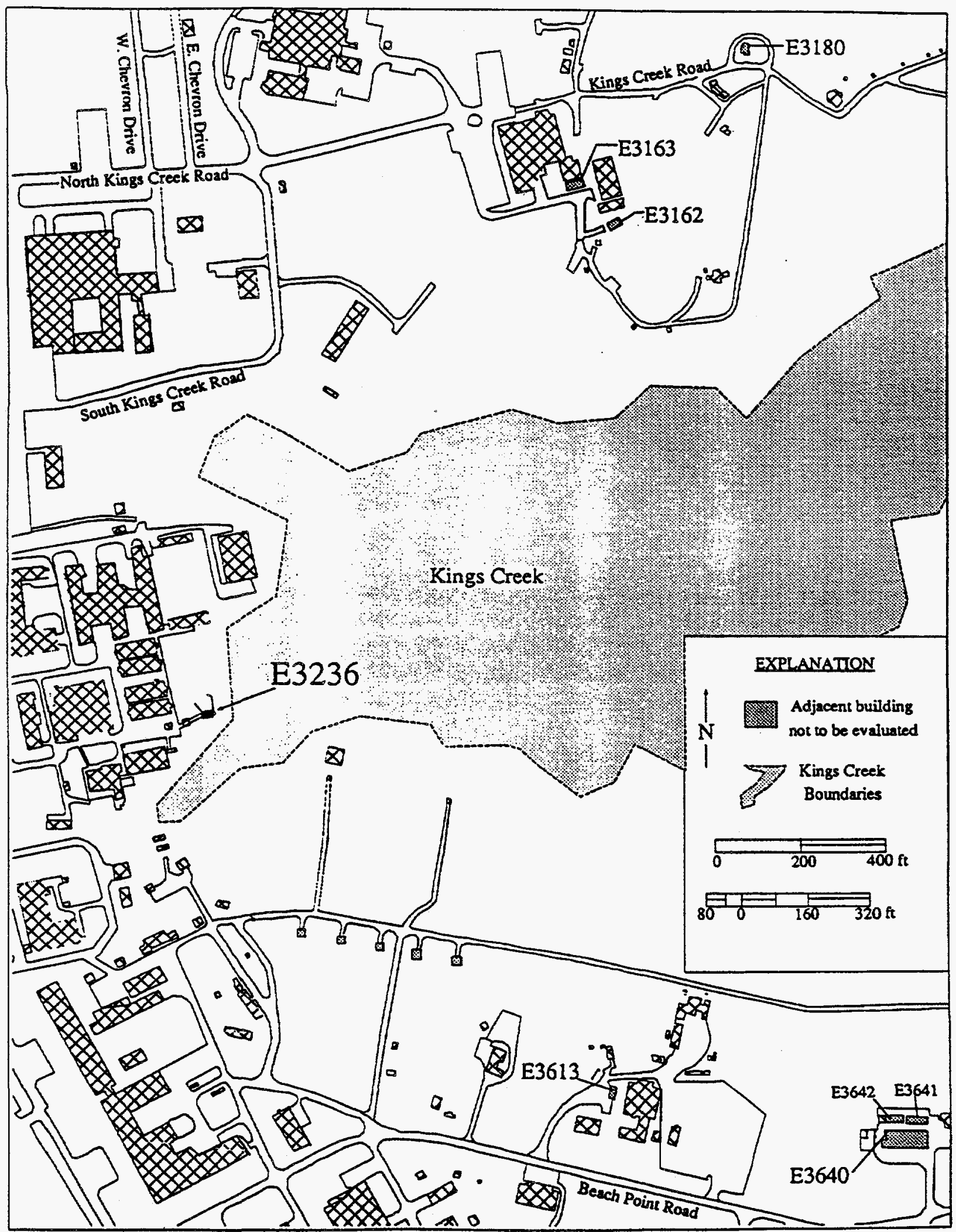

FIGURE 1 General Site Map of the Kings Creek Area, Aberdeen Proving Ground, MD 


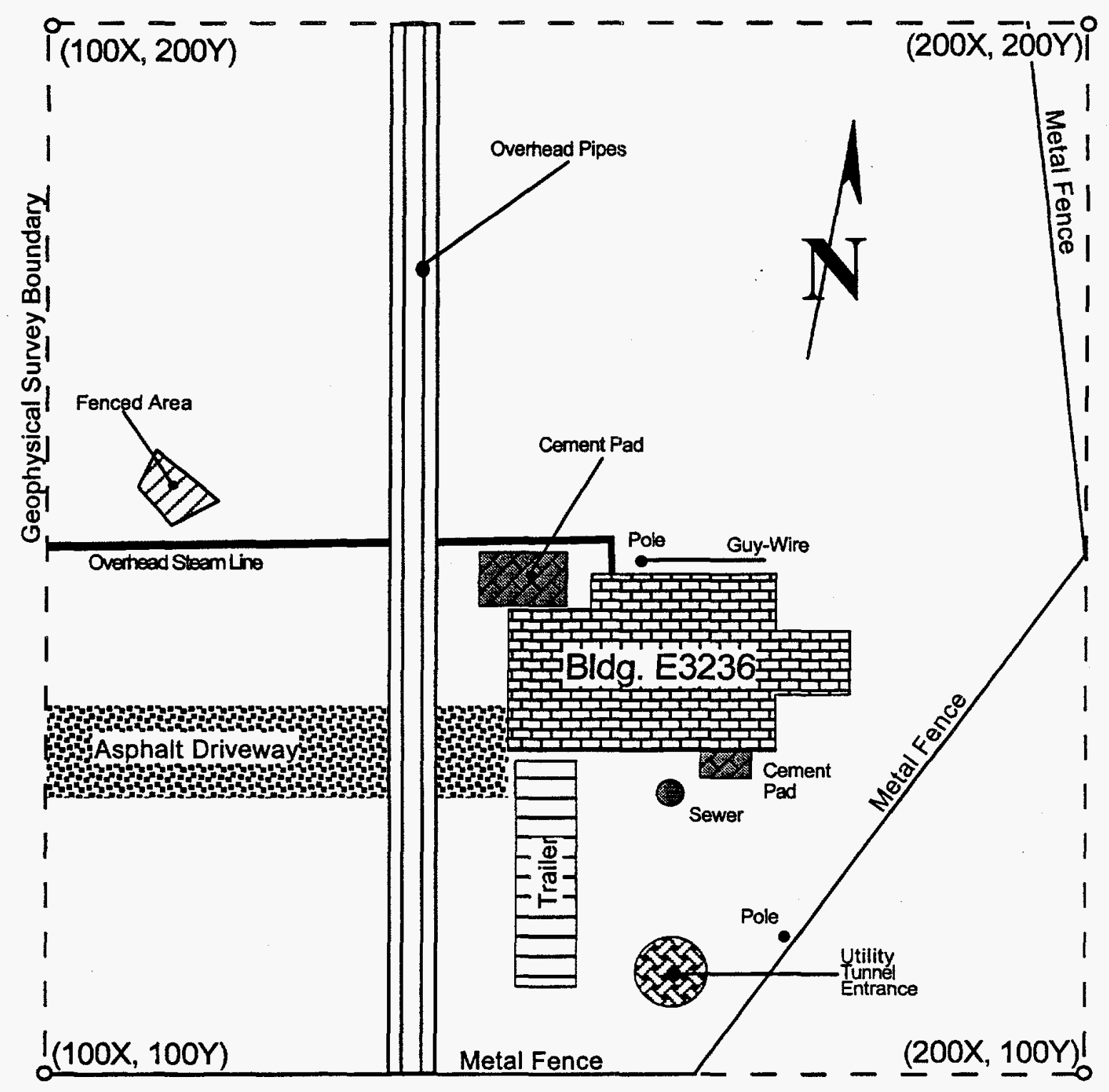

FIGURE 2 Detailed Location Map of Building E3236 
Creek area since the mid-1970s and currently no wastewater discharges to any surface water. There are currently accumulations of contamination at many of the E3200 buildings, especially at flammable storage cabinets near the buildings.

The building is located on level terrain that borders the western margin of Kings Creek (Figure 1). The site is accessible from all sides, and is covered with grass on the north, east, and south of the building. A steel fence forms the eastern and southern borders, limiting the extent of the geophysical survey area (Figure 2). 


\section{Instrumentation}

A survey grid was positioned so that its southwestern corner was located at coordinates $X=100, Y=100$, and was oriented so that its axes were parallel to the edges of the building which are oriented approximately east-west and north-south. Positive $\mathrm{X}$ and $\mathrm{Y}$ coordinates are measured approximately east and north of the starting coordinate (Figure 2). For convenience, a location of $X=100, Y=150$ will be represented as $(100,150)$. Within the geophysical survey area, physical properties of the subsurface were measured with three instruments along transects parallel to the $\mathrm{X}$ and $\mathrm{Y}$ axes. Instruments and transects include:

1. Continuously recording, total-field magnetometer (EG\&G Geometrics $\mathrm{G} 822 \mathrm{~L}$ ), with $\mathrm{Y}$ transects spaced $5 \mathrm{ft}$ apart and $\mathrm{X}$ tie lines spaced $5 \mathrm{ft}$ apart.

2. Time-Domain Geonics EM-61, designed for detection of metals, with $\mathrm{Y}$ transects spaced $5 \mathrm{ft}$ apart and $\mathrm{X}$ tie lines spaced $5 \mathrm{ft}$ apart.

3. Ground-Penetrating radar GSSI, SIR 3, with Y transects spaced $5 \mathrm{ft}$ apart. The locations of GPR profiles and their assigned reference numbers are shown in Figure 3.

EM-31 measurements were not made because of the close proximity of metals, including buildings, fences, and overhead steamlines. 
200

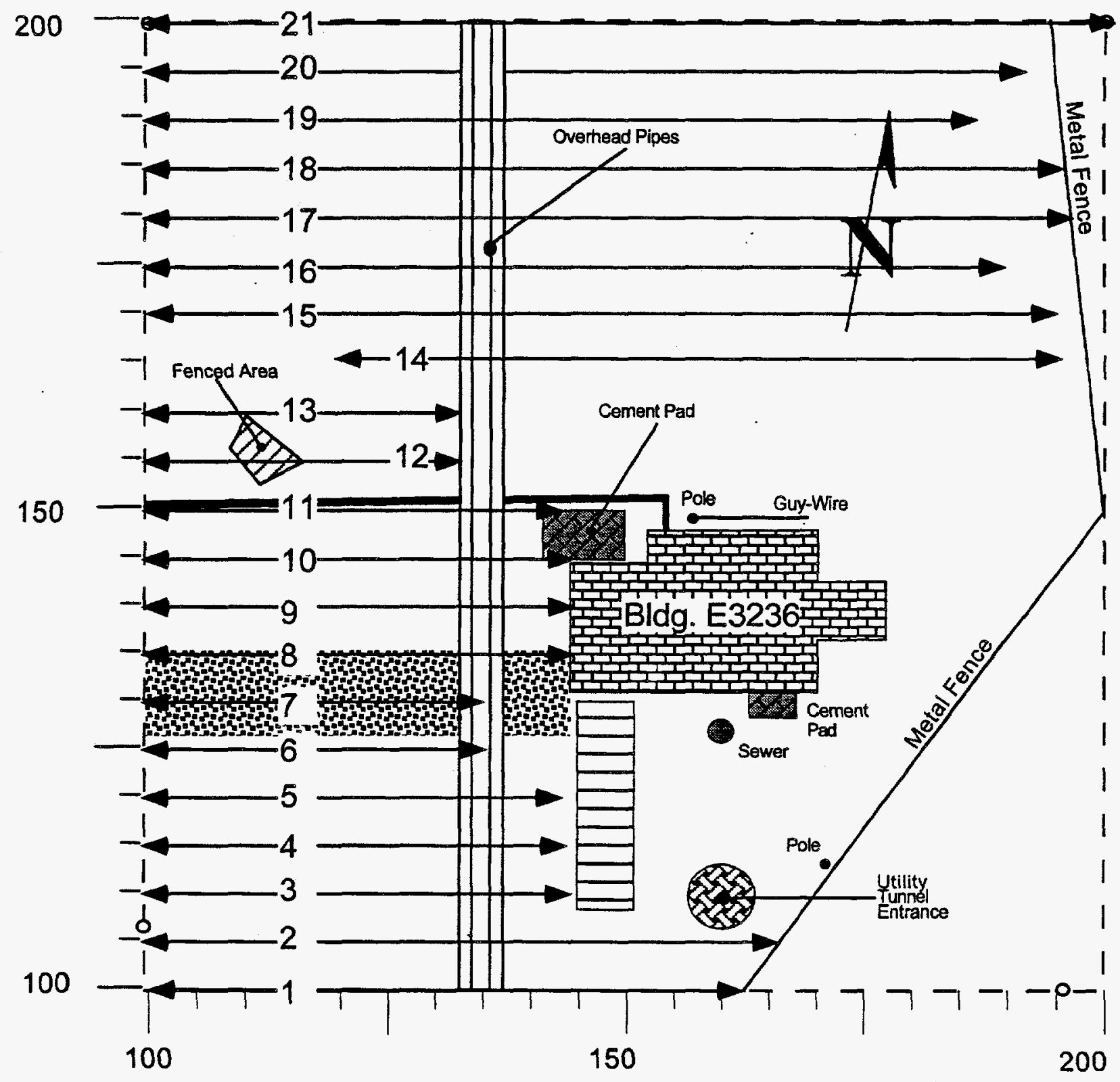

150

FIGURE 3 Map of GPR Transects Conducted Near Building E3236 


\section{Total Field Magnetics: G-822L}

A color-contour representation of the total magnetic field measured around Building E3236 is shown in Figure 4. Also shown are appurtenances associated with activity around the building and the location of the magnetometer profiles, which were run in both $\mathrm{X}$ and $\mathrm{Y}$ directions. Dominating the figure are magnetic lows associated with interference effects from the metal fence, the building, footings for the overhead pipe works, and a small fenced area (Figure 2). Combined, these anomalies form a NW-SE trending low that exits the survey area south of the NW corner.

The low magnetic anomalies located along the southern boundary may also be due to interference effects of a metal fence (Figure 2). On the other hand, isolated magnetic highs with centers at $(120,200)$ and $(120,130)$, and a more complex magnetic anomaly centered at $(107$, 115) have EM-61 counterparts and are probably sourced by a buried utility line. The source of the small-diameter magnetic anomaly centered on $(114,170)$ is unknown. 


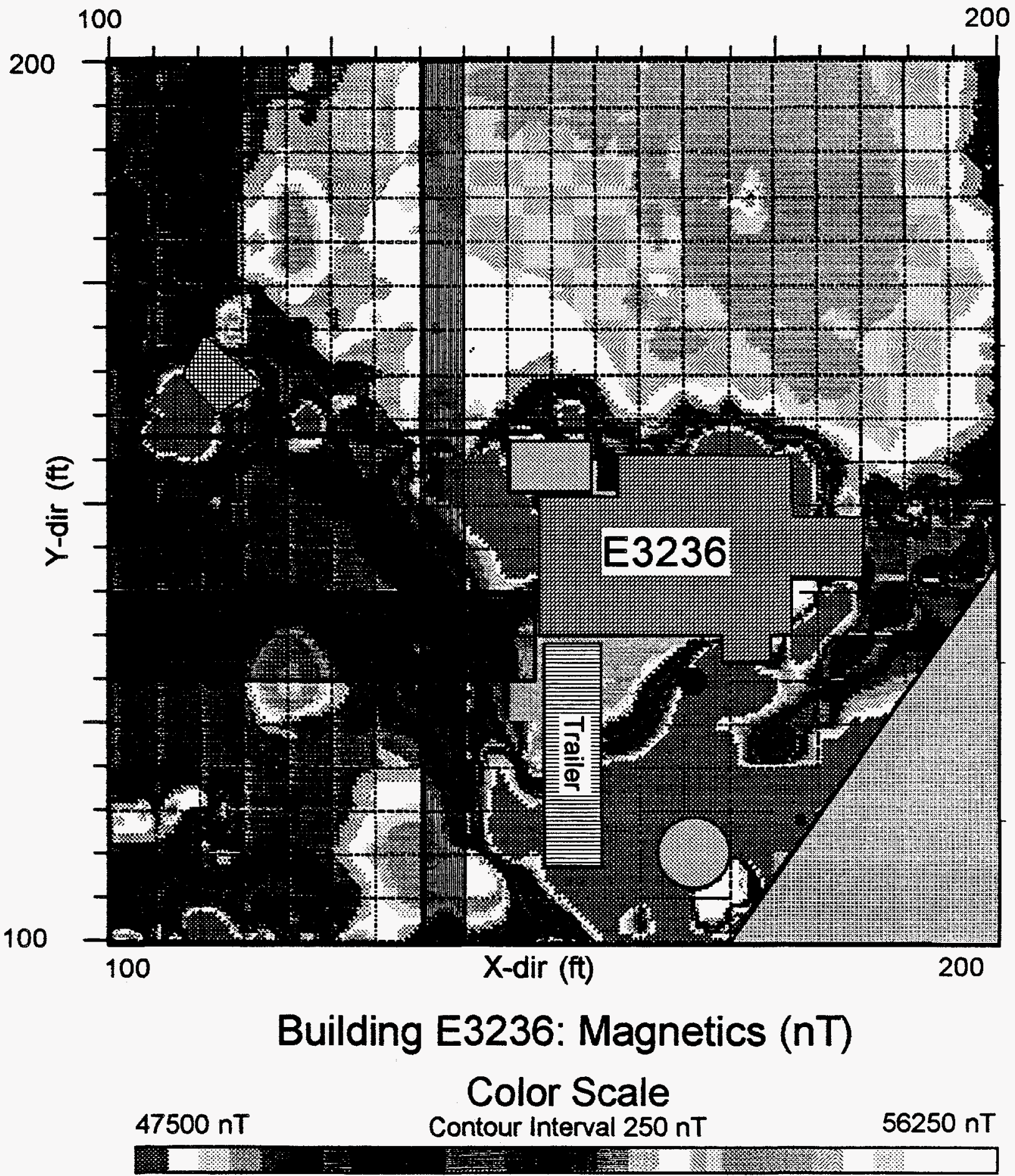

FIGURE 4 Total Magnetic Field Anomaly Map 


\section{Induced EMF Measurements: EM-61}

A color-contour map constructed from EM-61 lower coil data is shown in Figure 5. EMF positive anomalies are associated with the buildings, the overhead pipe works, the metal fence and a small metal-fenced area.

A prominent north-south trending EMF positive anomaly is observed along $X=120$. At about $Y=125$, this anomaly trends more westerly and appears to exit the survey area near the southwest corner. Isolated magnetic and GPR anomalies are also detected within this lineation, which may be sourced by a buried utility or water main.

Small diameter EMF positive anomalies are centered at $(100,200),(130,187)$ and $(100$, 135). The sources of these anomalies are unknown. 


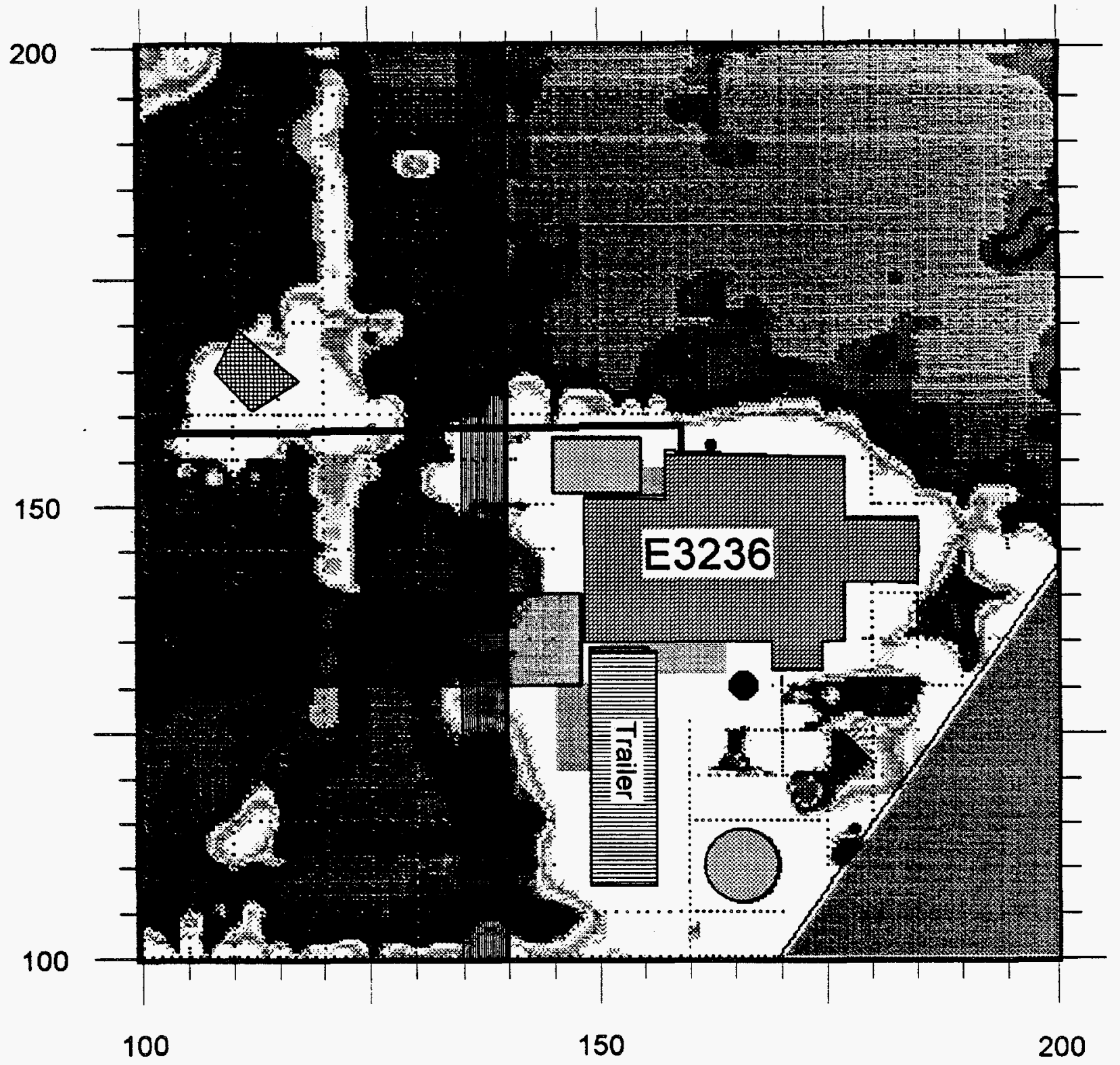

\section{Building E3236: EM-61 Lower Coil}

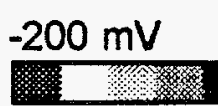

Contour Interval $=20 \mathrm{mV}$

FIGURE 5 EM-61 Millivolt Anomaly Map 


\section{Ground-Penetrating Radar Measurements}

Wave-velocity characteristics of near-surface materials were derived from tables of travel-time conversion to depth for various earth materials (Radan II 1992). For example, the two-way conversion to depth for average soil is $7-9 \mathrm{~ns} / \mathrm{ft}$. As the degree of soil saturation increases, the two-way conversion to depth also increases which, in effect, decreases the maximum penetration depth. Clay also tends to decrease the maximum penetration depth. At Building E3236, a range setting of $70 \mathrm{~ns}$ was used for the entire survey. Due to unknown saturation conditions and subsurface heterogeneities, the depth of penetration with GPR at E3236 can range between 7 and $11 \mathrm{ft}$ below the ground surface. For the purposes of this report, a maximum penetration depth of $10 \mathrm{ft}$ was assumed.

Good penetration was observed over most of the site. Isolated hyperbolas are detected along transects parallel to the $\mathrm{Y}$ axis at $\mathrm{X}=120-125$, near the observed linear EMF positive anomaly (Figure 6). In addition, strong reflections and shallow hyperbolas are observed along profiles $Y=100$ and $Y=105$ between $X=100$ and 120 . Subsurface disturbances caused by the nearby fence may explain these anomalies. However, the shallow hyperbola located at about $\mathrm{X}=127$ has a different and unknown source.

Isolated GPR anomalies are detected at $(160,105)$ and $(170,105)$ but do not correlate with anomalies detected by other geophysical techniques. The sources of these anomalies are unknown. 


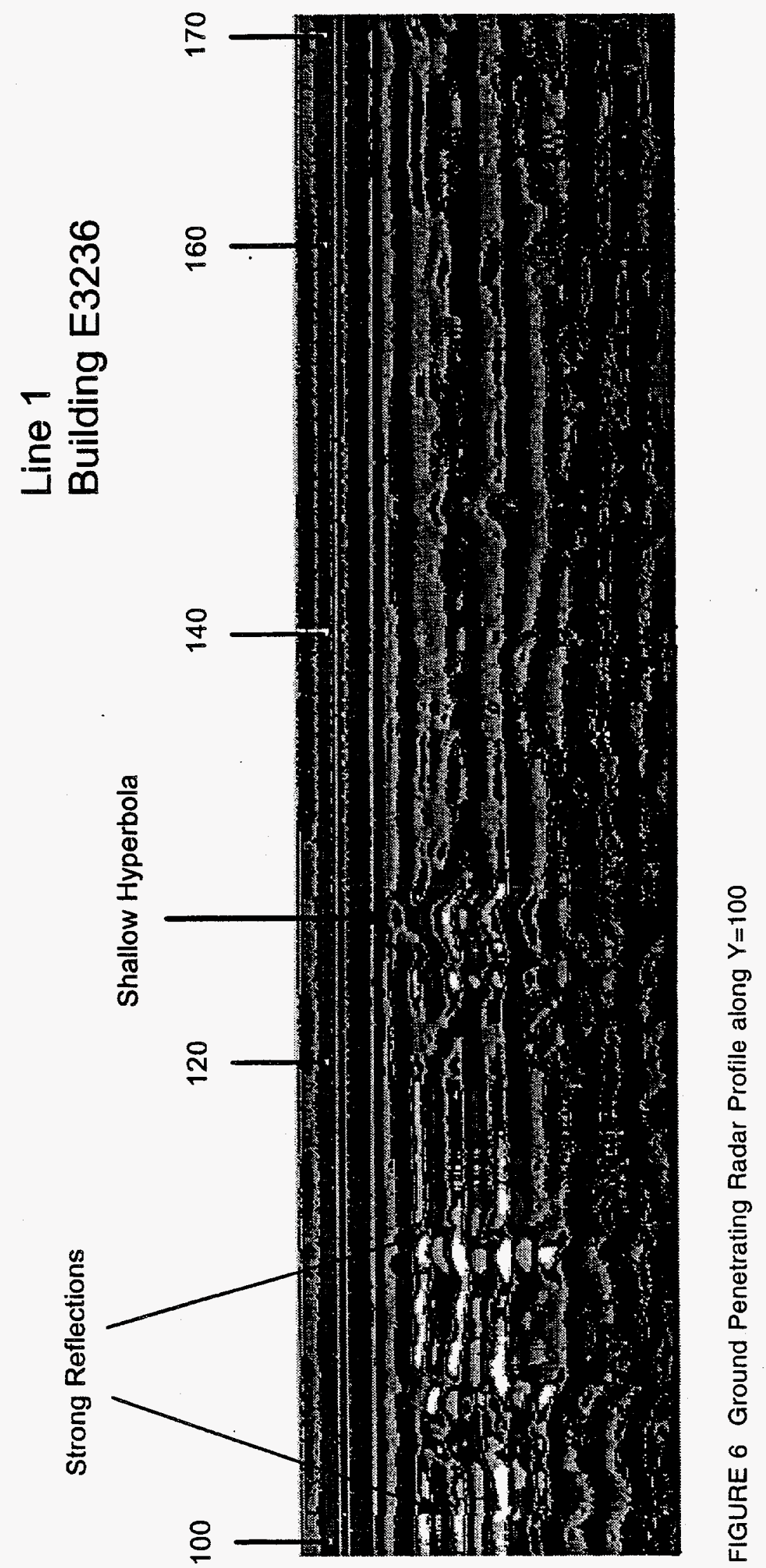




\section{Discussion}

Table 1 summarizes the locations of the observed geophysical anomalies around Building E3236, as well as their probable cause. Isolated magnetic anomalies are observed along the narrow north-south EMF positive anomaly (Figure 7) which are probably caused by joints/connections in an underlying utility line. Hyperbolic GPR anomalies are detected at shallow depths on at least seven EW transects near $X=120$.

Near the fence along the southern border of the survey area, hyperbolic GPR anomalies are detected along transects $Y=100$ and $Y=105$, suggesting an anthropogenic source distinct from the fence. Although EMF and magnetic anomalies are also present, their interpretation is enigmatic because interference from the fence must contribute, at least in part, to these signals.

Geophysical anomalies are detected near buildings, overhead pipelines and metal drains. In these areas, anomalies caused by a buried source are obscured by interference effects of visible structures. Therefore, any underground pipelines that may have connected E3236 to the marshes east and northeast of the building can not be detected with the available geophysical data.

A few isolated magnetic, EMF and GPR anomalies are also observed are not spatially associated with each other. The sources of these anomalies are unknown (see Table 1). 


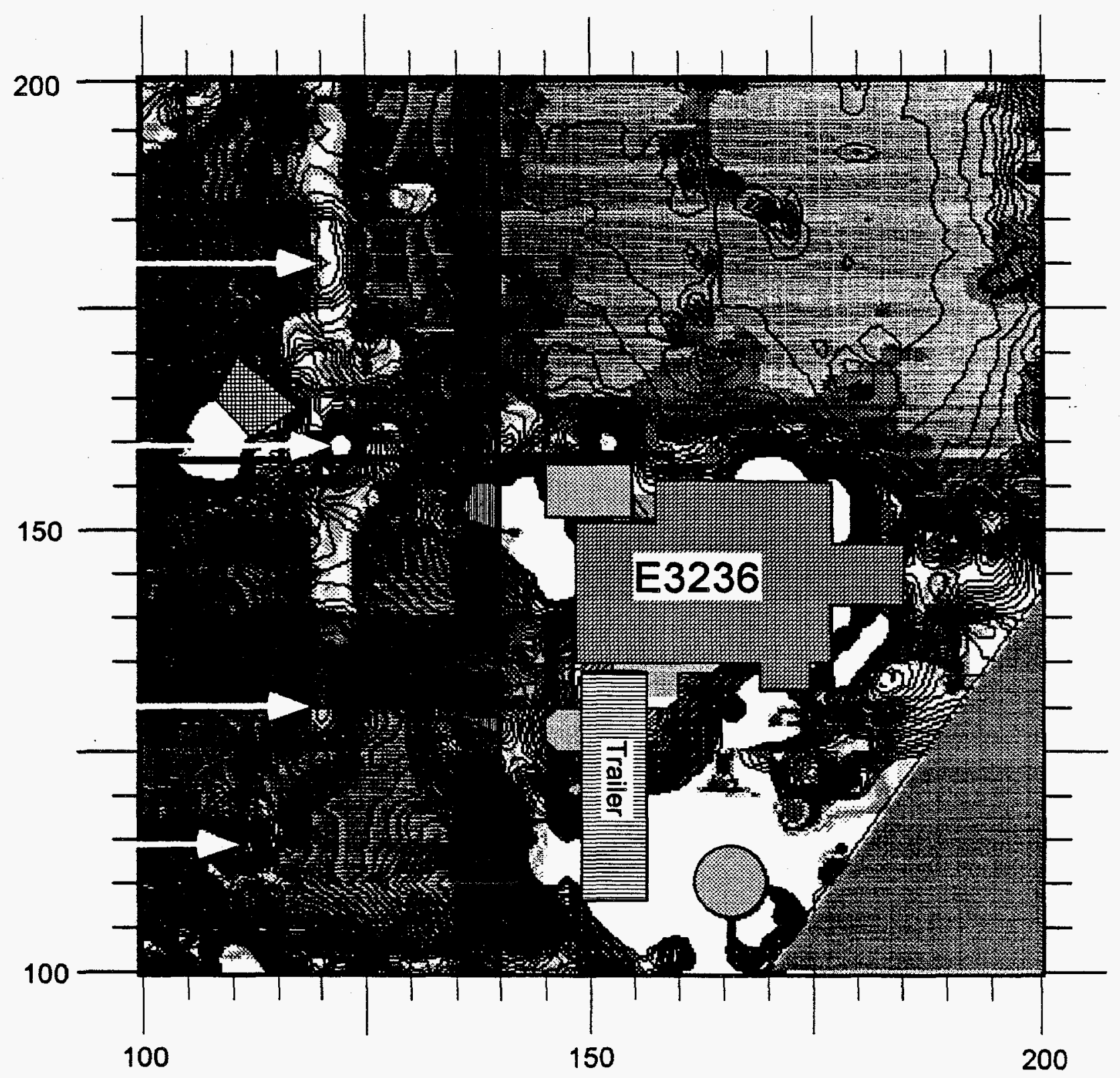

Building E3236: EM-61 Lower Coil w/Magnetics Overlay

$-200 \mathrm{mV} \quad$ Color Scale $\quad 360 \mathrm{mV}$

Magnetic Field Contour Line Interval $=150 \mathrm{nT}$

FIGURE 7 EM-61 Millivolt Anomaly Map with Overlay of Magnetic Field Contours 
TABLE 1 Location and Description of Geophysical Anomalies Detected near Building E3236

\begin{tabular}{|c|c|c|c|c|c|}
\hline \multicolumn{2}{|c|}{ Coordinates } & \multicolumn{3}{|c|}{$\begin{array}{l}\text { Geophysical } \\
\text { Instrument* }\end{array}$} & \multirow[t]{2}{*}{ Possible Origin } \\
\hline $\mathbf{x}$ & $\mathbf{Y}$ & $\frac{1}{80}$ & $\begin{array}{l}\text { 采 } \\
\dot{\omega}\end{array}$ & $\stackrel{0}{0}$ & \\
\hline 120 & $120-200$ & $\checkmark$ & $\checkmark$ & $\checkmark$ & Source unknown, Buried utility \\
\hline 100 & 200 & & $\checkmark$ & & Source unknown \\
\hline 130 & 187 & & $\checkmark$ & & Source unknown \\
\hline 100 & 135 & & $\checkmark$ & & Source unknown \\
\hline $140-180$ & $100-160$ & $\checkmark$ & $\checkmark$ & & Interference from buildings \\
\hline 112 & 165 & $\checkmark$ & $\checkmark$ & $\checkmark$ & Small Fenced Area \\
\hline 114 & 170 & $\checkmark$ & & & Source unknown \\
\hline 160 & 105 & & & $\checkmark$ & Source Unknown \\
\hline 170 & 105 & & & $\checkmark$ & Source Unknown \\
\hline $100-140$ & $100-105$ & $\checkmark$ & $\checkmark$ & $\checkmark$ & Metal Fence and unknown source \\
\hline
\end{tabular}




\section{Conclusions}

Site geophysical surveys consisting of total field magnetics, EM-61 millivolt, and ground-penetrating radar around Building E3236 permit the following conclusions:

- A linear EMF anomaly is observed between $(120,115)$ and $(120,200)$, which is probably sourced by a buried metal pipe or utility. Magnetic anomalies are observed along this linear feature. In addition, isolated GPR hyperbolas detected along this lineation suggest that this feature is shallowly buried.

- GPR anomalies are detected along two transects near the southern-most metal fence which suggest an anthropogenic source. Magnetic and EMF anomalies are also detected in this area, however, interference from the fence prevents interpretation with certainty.

- Magnetic and EMF anomalies are observed near the building, the overhead pipes and metal fences.

- Isolated magnetic, EMF and GPR anomalies are detected in the area; however, they are not spatially associated. The sources of these anomalies are unknown. 


\section{References}

EAI Corporation, 1989, Historical Records Search and Site Survey of Edgewood Area Buildings, Final Report, prepared by EAI Corporation, Abington, Md., for U.S. Army Chemical Research, Development, and Engineering Center, Aberdeen Proving Ground, Md., under contract No. DAA15-87-D0021.

Geophysical Survey Systems, Inc., 1987, Operations Manual Subsurface interface Radar, SIR System-3

Nemeth, G., 1989, RCRA Facility Assessment Report, Edgewood Area, Aberdeen Proving Gound, Maryland, 21010-5422, No. 39-26-0490, United States Army Environmental Hygiene Agency, Aberdeen Proving ground, Md. 
